\title{
He Came, He Saw, He Conquered?: The Expeditio litteraria ad Polum Arcticum
}

\author{
In these northern regions, so rarely visited and so little explored, \\ everything is of interest, and Father Hell studied everything. \\ JÉRÔME DE LALANDE ${ }^{1}$
}

To commission a high-quality, internationally respected astronomical observation and thus restore Denmark's dwindling fame as a "nation of astronomy" was no doubt the chief ambition of Hell's sponsors. In the very first letter from Foreign Minister Bernstorff to his Viennese envoy, the only explicit aim of the expedition is observation of the transit of Venus from Vardø. ${ }^{2}$ Although the expedition's timeframe expanded significantly, with the departure from Vienna finally set more than a year ahead of the astronomical event, there is no evidence in the ensuing diplomatic correspondence between Vienna and Copenhagen to suggest that Denmark-Norway was preparing to support a wholescale encyclopedic expedition entailing years of exploration and voluminous publications. ${ }^{3}$ Such plans, however, soon took form in Hell's mind. Besides bending to God's will, Hell must have been all too aware that to the Republic of Letters the region in question was still virtually a terra incognita. It was exotic and "liminal," with the aurora borealis, polar night, and midnight sun, along with extreme weather and natural dangers such as the maelstrom of Moskenes, and above all the indigenous Sámi (Saami, Sami) population-known in those days as "Lapps" - forming intriguing objects of study with a broad popular appeal. ${ }^{4}$ The Lapland voyages of Linnaeus and Maupertuis in the 1730 s had

1 Jérôme de Lalande, Bibliographie astronomique avec l'histoire de l'astronomie depuis 1781 jusqu’à 1802 (Paris: Imprimerie de la République, 1803), 721.

2 Letter from Bernstorff to Bachoff in Vienna, dated Copenhagen, August 18, 1767 (RA).

3 Letters from Bernstorff to Bachoff in Vienna, dated Copenhagen, October 3, 1767 and February 20, 1768 (RA); letters from Bachoff to Bernstorff in Copenhagen, dated Vienna, September 7, 1767 and October 29, 1767 (RA).

4 Sven Widmalm, Mellan kartan och verkligheten: Geodesi och kartläggning, 1695-1860, Institutionen för idé- och lärdomshistoria, Uppsala universitet, Skrifter 10 (Uppsala: Institutionen 
emblematic status, but they did not reach the area targeted by the Hell expedition, which thus held out the promise of a wealth of new information capable of breaking new ground in several fields of knowledge. This chapter describes how the Vardø expedition, originally conceived as confined to astronomical observation, turned into a more comprehensive scientific endeavor of virtually encyclopedic scope, with astronomy forming only a part of the research program.

A Journey Finished and Yet Unfinished

Hell's idea of expanding the scientific ambitions of an astronomy-motivated expedition was by no means unique. Besides curiosity, some of the motivation was purely pragmatic and utilitarian. A statement by Cassini de Thury in a paper on the Venus transits in the proceedings of the Académie Royale des Sciences is typical:

When such long voyages are undertaken, one must have more than one object, so that in case the essential goal cannot be accomplished, it will be possible in some measure to remedy the damage. Otherwise, one may be forced to take comfort in having traveled more than a thousand leagues only to gaze at the Sun for six hours and find it eclipsed, not by the planet, but by a cloud. ${ }^{5}$

Closer to home, a similar view was expressed by Scherffer in a letter to Weiss as early as 1750, offering Weiss advice on the aims and scope of a planned expedition to survey the Portuguese dominions in Brazil. Scherffer emphasized that his colleague should prepare to undertake not only geodetic work but also to make delicate barometrical observations, investigate the running of pendulum

för idé- och lärdomshistoria, Uppsala universitet, 1990), esp. 183-85; Florian Wagner, Die Entdeckung Lapplands: Die Forschungsreisen Carlvon Linnés und Pierre Louis Moreau de Maupertuis' in den 1730er Jahren (Norderstedt: Books on Demand, 2004), esp. 22-30; Päivi Maria Pihlaja, "The Study of the North in the 18th Century: Knowledge of Lapland in Europe, and Its Significance for Foreign Scholars," in The North Calotte: Perspectives on the Histories and Cultures of Northernmost Europe, ed. Maria Lähteenmäki and Päivi Maria Pihlaja, Helsingin yliopiston historian laitoksen julkaisuja 18 (Inari: Puntsi, 2005), 25-37; Sigri Skjegstad Lockert, Havsvelget i nord: Moskstraumen gjennom årtusener (Stamsund: Orkana akademisk, 2011); Alessandra Orlandini Carcreff, Au pays des vendeurs de vent: Voyages et voyageurs en Laponie et Finlande du XVe au XIXe siècle (Aix: Presses universitaires de Provence, 2017).

5 César-François Cassini de Thury, "Remarques sur la conjonction de Vénus avec le Soleil, qui doit arriver le 6 Juin de l'année prochaine 1761," HARS (1762; paper read November 12, 1760): 334 . 
clocks, undertake numerous geophysical observations, and so on-in short, "to describe the Brazilian lands" in all their diversity:

I confess that, if merely one of these aspects are left out [of the expedition's research program], there will be no one in Europe who will explain that defect by pointing to the expedition's mandate, the hardships endured, the wants of the instrumentation, the limited staff, or the [king's] parsimony in the expenses: surely, every person will blame it on the ignorance of Jesuits abusing the treasuries of kings. ${ }^{6}$

In other words, as Scherffer saw it, ensuring a broad expedition program was especially important when Jesuits were concerned in order to ward off attacks by anti-Jesuits. Returning to Hell's own point of view, he assured the readers of the official Venus transit report, published in Copenhagen in February 1770, that "nor have we neglected the facts that throw light on or supplement the natural history of the animal and vegetable world, such as mussels, herbs, algae, mosses, and making other observations especially useful in regard of their economic applications" and the "origins, language, and different dialects of the Lappian nation living scattered in the north." Thus, even if "as a result of adverse weather conditions [...] I were to be disappointed in regard of the often mentioned observation, this scientific expedition were still not entirely fruitless for the sciences and the useful arts." ${ }^{7}$ While "Sámi studies" obviously benefited hugely from the expedition, whatever specimens of the mentioned items of the flora and fauna Hell and his associates might have collected and brought back with them from the journey, the sources contain virtually no information about their fate. It is thus a question of whether this remark is a genuine account of their pursuits, or merely a gesture toward the practices and the topoi of exploration in the eighteenth century. In any case, it is important that the enlightened language of improvement was just as appropriate to frame his thoughts on the prospective yields of the northern expedition for the Viennese Jesuit as it had been for Linnaeus or Maupertuis.

After spending eight and a half months in the treeless, Arctic scenery of Vardø, Hell and Sajnovics left the island on June 27, 1769. They took their time on the return journey. After sailing past the huge Varanger Peninsula, on the east side of which Vardø is situated, they allowed themselves a detour to the settlements of Talvik and Alta in the innermost part of a fjord, some sixty kilometers away from the direct sea route to Trondheim. Here, they enjoyed the

6 Scherffer to Weiss, dated [Graz], August 2, 1750, in Vargha, Correspondence de Weiss, 10-11, here 11 .

7 Hell, Observatio transitus Veneris [...] 1769, 4. 
sociability of Eiler Hagerup (1736-95), the senior district stipendiary of Finnmark, in whose agreeable company they had already spent several weeks when they traveled north from Trondheim the previous year. They also met historian and translator of the ancient laws of Norway Hans Paus (1710-70) and surveyor of western Finnmark and amateur astronomer Christian Frost Bredahl (17171811). ${ }^{8}$ Years later, Hell remembered his visit to Talvik in colorful terms:

There is hardly a place in the European part of the world surpassing it in beauty. Toward the end of July, when I visited this place surrounded by high mountains at roughly one mile's distance, I saw the most idyllic forests with various sorts of trees, luxuriant fields, and gardens with blossoming plants belonging to the zone of temperate climate, among them carpets of flowering Linneas [Linnaea borealis]. The summits wrapped in snow, the hillsides covered with green trees, and spring meeting summer in the valleys, were a wonderful sight. Then, there was the refreshing air, the sweetest of Zephyrs blowing, in a day that knows no night. Therefore this place, at the seventieth latitude, is rightfully called the "Paradise of Finnmark" by its inhabitants. Bewildered, I found this to be what it really was-a paradise. ${ }^{9}$

They also spent several days in the port of Tromsø, no doubt motivated by Borchgrevink's wish to pay a family visit to his sister and brother-in-law, who worked there as a priest. In total, the return journey to Trondheim lasted a good nine weeks, this time not primarily as a result of adverse winds (although they had their share of them as well) but because the Jesuit wanted to explore the area and cultivate friendships. There is no reason to characterize this as a pause from Hell's otherwise devoted adherence to the scientific goals of the expedition. Interaction with local informants was of utmost importance to eighteenth-century traveling explorers. Ultimately, any fruitful collection of information was based on sociability. In an addition to the diary from the stay in Tromsø, Sajnovics noted:

The Lapps that are in the area of Tromsø stay here for no more than seven or eight weeks. Their winters are spent in Sweden. And since they are unable to speak Norwegian, they carry with them [written] testimony from

8 Sajnovics, travel diary, draft version (wUs), on July 22-27, 1769 .

9 Hell, "Observationes astronomicae latitudinum, et longitudinum locorum borealium Daniae, Sueciae, et Finnmarchiae Lapponicae per iter arcticum annis 1768, 1769, et 1770 factae," Ephemerides 1791 (1790): 300-86, here 321. Translation in Lynne Hansen and Aspaas, Maximilian Hell's Geomagnetic Observations, 34. 
a Swedish priest confirming that they did attend service during wintertime. On his recommendation, during summertime they are even here [in Tromsø] allowed to Holy Communion without declaration of faith or examination. ${ }^{10}$

Questioning the degree of success by the Danish crown in bringing Sámi subjects under its jurisdiction and into religious conformity through mission was a standard element of descriptions of the indigenous people of the north in eighteenth-century global geographies. It was not uncommon that travel accounts, rather than providing original observations on such matters, simply repeated the stereotypes found in the relevant literature. This seems not to be the case with Sajnovics's remark: the precious piece of information was obviously revealed to the Jesuits directly during conversations with locals, whose confidence they could only gain by taking their time.

Moreover, Hell and Sajnovics wanted to measure the geographic latitude of as many places as possible. In the absence of visible stars during the Arctic summer months, this act of surveying was only feasible at the time when the Sun reached its highest point at midnight or at noon. ${ }^{11}$ In the same process, it was also possible to determine the axis of true north and south, which in turn was a prerequisite for the measurement of the slightly varying deviation of the compass needle from true north. ${ }^{12}$ Many a short stop was therefore prolonged for a couple of hours or more, so that the local pole height as well as the degree of magnetic declination could be measured. Similarly, the curiosity of the two Jesuits also induced them to inspect marks of old shorelines formed ages ago and to measure their distance from the present sea level (in Hamningberg, Kjelvik, and Måsøy):;3 to engage in climbing to measure the height of mountains

10 Sajnovics, a sheet of paper named "Supplementa Diarij” (wUs).

11 Hell summarized these observations in the report Latitudines geographicae locorum Finmarchiae, Nordlandiae, Norwegiae et Sueciae observationibus astronomicis definitae à Maximiliano Hell (manuscript, National Library of Norway, MS $4^{\circ}$ 16), published in Danish translation as "Nogle Steders Geographiske Breder i Finmarken, Nordlandene, Norge og Sverrige bestemmede ved astronomiske Observationer [...] og overgivet det Kongelige Videnskabernes Selskab i Kiøbenhavn den 18 May 1770. [...] af det Latinske Sprog oversat paa Dansk af Henrich Hövinghoff," Skrifter Kiøb. 10 (1770): 619-52, and, twenty years later, in an expanded Latin version in Hell's own Ephemerides, "Observationes astronomicae latitudinum [...]."

12 Aspaas and Lynne Hansen, Maximilian Hell's Geomagnetic Observations; Aspaas and Lynne Hansen, "Geomagnetism by the North Pole."

13 Hell's manuscript "Methodus observandi declinationes acus magneticae per iter litterarium ad Polum boreum" (wus; facsimile in Aspaas, "Maximilian Hell og Johannes Sajnovics," 68, and in Lynne Hansen and Aspaas, Maximilian Hell's Geomagnetic Observations, 61-105), entries on July 8 and 19, 1769 . 
by means of barometers (in Kjelvik); ${ }^{14}$ to catch and make sketches of species of jellyfish (at Havøysund) ${ }^{15}$ to collect specimens of hermit-crabs on the shore and cook them for long-term preservation (at Selsøya); ${ }^{16}$ and so on.

When they finally reached Trondheim on August 30, another two weeks were spent in the company of Gunnerus and other notables, including General von der Osten and his Catholic soldiers, who were again offered a string of "church" services at Kristiansten fortress. Prominent among the persons who greeted Hell was the city mayor and littérateur Niels Krog Bredal (1733-78), whose slightly mock-heroic poem on the occasion contains reference to the Keeper of the Winds in Greco-Roman mythology (Aeolus), the gods of the Sun and the sea (in the guise of Phoebus and Neptune, respectively), as well as an allusion to the conquests of Julius Caesar by the immortal phrase veni, vidi, vici (I came, I saw, I conquered):

What truth there is in the declarations of prophets, you now know, My sweet friend! You return, having achieved what you prayed for. Narrow straits do not scare you, nor shipwrecking reefs; Neither the ice-covered sea, nor the polar winter nights.

The Alps dressed in fog, the long-lasting winter with its eternal masses of snow;

None of that is capable of preventing your voyage.

You come [venis], you see [vides] everything that is worthy of being observed;

You conquer [vincis] the Gods that are up against you from either side.

The heroic endeavor was favored by Phoebus, Venus, and Aeolus, As well as by all the spirits that Neptune has under his sway.

I congratulate you! Now safely return to visit the Penates of your own: May the Gods hear my prayers this time as well! ${ }^{17}$

Many years later, the heroic explorer, who "sees everything that is worthy of being observed," included Bredal's poem in an article in the Ephemerides. Some

14 Hell's manuscript "Methodus observandi," as reproduced in Lynne Hansen and Aspaas, Maximilian Hell's Geomagnetic Observations, entry on July 7, 1769 .

15 Hell's manuscript "Methodus observandi," as reproduced in Lynne Hansen and Aspaas, Maximilian Hell's Geomagnetic Observations, on July 19, 1769 .

16 Sajnovics's travel diary, draft version (wUs), on August 17, 1769 .

17 Latin poem in Bredal's own hand, dated September 1, 1769 (wUs); edited with translation in Per Pippin Aspaas, "Astronomy, Latinity, Enlightenment: Niels Krog Bredal's Poems Commemorating the Transits of Venus, 1761 and 1769," Symbolae Osloenses 90 (2016): 205-34, here 224 . 
of the sting was taken out of the poem, however, when he as editor took the liberty of altering the phrase into "everything that was visible in the sky."18

In the continuation of the reverse trip, Hell and Sajnovics followed exactly the same route as in the previous year-through Christiania, Fredrikshald, Gothenburg, Helsingborg, and Helsingør - to Copenhagen, which they finally reached on October 17. Here, they stayed until May 22 the next year, meanwhile engaging extensively with local men of learning as well as with members of the nobility and the royal family.

By the time Hell began writing his official paper on the Venus transit observation, the chief goal of the expedition had indeed been accomplished. Not only Hell but also Sajnovics were soon honored with memberships of the two royal scientific societies in the realm, in Trondheim and Copenhagen, respectively. Yet, the Venus transit expeditionists allowed themselves no rest on their laurels, but systematized and checked the results of their wide-ranging observations and experiments by consulting the available expertise and stock of literature in the capital. Spending their nights in the house of the Austrian embassy, they had living quarters comfortable and peaceful enough to enable them to work on the wealth of information they had gathered and to compose scientific works that - as they hoped—would bring them lasting fame.

While in Copenhagen, Hell and Sajnovics regularly visited the sessions of the Royal Society of Sciences, which were held at the residence of Minister Thott. Three long reports and a comparatively short one were produced and presented to the society in this period. Beginning with the official Venus transit report (read during three sessions in November-December 1769), ${ }^{19}$ there followed a famous "Demonstration That the Language of the Hungarians and the Lapps Is the Same" by Sajnovics (three sessions in January-February 1770), ${ }^{20}$ a "New Theory of the Aurora Borealis" by Hell (five sessions in March 1770), ${ }^{21}$ and finally, "The Geographical Latitude of Several Places" (manuscript submitted in May 1770$).{ }^{22}$ In each of these papers, all subsequently printed and distributed through respected Danish and Habsburg publication outlets, the two Jesuits made sure to emphasize that the texts in question were really just sections

18 Hell, "Observationes astronomicae latitudinum [...]," 361. For details, see Aspaas, "Astronomy, Latinity, Enlightenment."

19 Protocol of meetings, archives of Det Kongelige Danske Videnskabers Selskab (DKDVs), entries November 17, November 24, and December 1, 1769 .

20 DKDVs, entries January 26, and February 2 and 91770.

21 DKDVs, entries March 2, 9, 16, 25, and 28, 1770.

22 Latitudines geographicae locorum Finmarchiae, Nordlandiae, Norwegiae et Sueciae observationibus astronomicis definitae à Maximiliano Hell (manuscript, National Library of Norway, MS $4^{\circ}{ }_{16}$ ). 
of a larger work that Hell was preparing, the Expeditio litteraria ad Polum arcticum. ${ }^{23}$ This grand work, never accomplished in its entirety, merits some consideration as it seems to have functioned as an important vehicle in Hell's attempt at promoting himself as an explorer with first-hand knowledge of - and thereby legitimate authority also to interpret and explain— "everything" in the Far North.

Judging from the correspondence of Hell from the period ${ }_{1768-70}$, the idea of a grand encyclopedic work on the Far North was present in his mind from the outset of his journey. The first reference to the title as such is in a letter to his substitute in Vienna, Anton Pilgram, dated Vardø, April 30, 1769: "My observations, which I have either made or am going to make here in Vardø, will be reserved for the Expeditio litteraria ad Polum arcticum." ${ }^{44}$ As mentioned, Hell and Sajnovics made sure to mention this plan in all the various papers presented to the Society of Sciences in Copenhagen, although there they solely used the form Expeditio litteraria. A more elaborate description of the work (this time with its full title) was issued later in 1770, in the form of a call for subscriptions that was included in the Leipzig journal Nova acta eruditorum and also issued as a separate leaflet in both Latin and German in Vienna, from where it was distributed far and wide in the Republic of Letters. ${ }^{25}$

It is tempting to translate the title of the prospective magnum opus as "Literary Expedition to the North Pole," as has been done by several scholars. ${ }^{26}$ However, the only word that is unproblematic in that translation is expeditio, expedition. The adjective litterarius in its early modern version has little to do with belles-lettres. Rather, it emerges from litterae as it appears in respublica litteraria (Republic of Letters, république des lettres, Gelehrtenrepublik, den lcerde republikk). The nearest modern equivalent would be "scientific," allowing for a broad concept encompassing bookish erudition as well as natural philosophy and empirical natural knowledge. Hell's great astronomer

23 Hell, Observatio [...] 1769, esp. 2-6, 17, 61; Sajnovics, Demonstratio [...] (1770), 82; Hell, “Aurorae borealis theoria nova [...] Pars I," Ephemerides 1777 (1776), 2; Hell, "Nogle Steders Geographiske Breder," 621.

24 Printed in Pinzger, Hell Miksa, 2:93-95, here 94.

25 Nova acta eruditorum (September 1770): 427-32. While no comprehensive search for mentions of the Expeditio litteraria ad Polum arcticum in contemporary journals and magazines has been undertaken, it is telling that the Journal des Sçavans included a detailed summary of the call for subscriptions in July 1771 (see 499-500). By then, the Jenaische Gelehrte Zeitung had issued a similar summary in June 1771 (no. 48), 399-400, whereas the Staats- und Gelehrte Zeitung des Hamburgischen unpartheyischen Correspondenten had published the entire text in the original Latin, March 9 (no. 40), March 12 (no. 41), March 13 (no. 42), and March 15 (no. 43), 1771.

26 Sarton, "Vindication," 104; Kragemo, "Pater Hells Vardøhusekspedisjon," 122. 
contemporaries used vernacular equivalents of the word exactly in this sense, even referring to expeditions. As Nevil Maskelyne (1732-1811) summed up the historical significance of British participation in the ${ }^{1761}$ Venus transit project in a letter to the president of the Royal Society of London:

Nor can the learned world but look upon themselves as highly indebted to your Lordship, for that noble zeal, which you have manifested for the improvement of astronomy, in setting forward, and promoting, these literary expeditions, which tend to the benefit of mankind, and the honour of our native country [italics added]. ${ }^{27}$

Literary, or littéraire, had a similar meaning in French. Lalande, in one of his letters to Weiss, asked him to address his letters to the Académie Royale des Sciences, so that the academy would cover the postage. This would be quite legitimate, he proceeded, for what they were dealing with was "above all observations and literary correspondence [correspondance litteraire]," that is, contents worthy of being paid for by the academy. ${ }^{28}$ Finally, when Hell's planned work was referred to in contemporary translations into Danish, the title was regularly rendered Det laerde Tog. ${ }^{29}$ The epithet loerd is associated with the noun Videnskab (Wissenschaft), implying both erudition and empirical science, but hardly works of fiction, which nowadays appears to be the primary connotation of "literary."30

27 Nevil Maskelyne, "An Account of the Observations Made on the Transit of Venus, June 6, 1761, in the Island of St. Helena: In a Letter to [...] George Earl of Macclesfield, President of the Royal Society, from the Rev. Nevil Maskelyne [...]. Read Nov. 5, 1761" PTRSL (1762), 196201, here 200.

28 Lalande to Weiss in Trnava, dated Paris, August 7, 1768, in Vargha, Correspondance de Weiss, 68.

29 See, e.g., Maximilian Hell, "Observation over Veneris Gang forbi Soelens Skive den 3 Junii 1769. anstillet i Wardøhuus efter den Stormægtigste og Allernaadigste Konge til Dannemark og Norge \&c. \&c. Kong Christian den Syvendes Befalning, og forelæst det Kongelige Videnskabernes Selskab i Kiøbenhavn den 24 November 1769. af Maximilian Hell. Oversat af det Latinske i det Danske Sprog af Henrich Hövinghoff," Skrifter Kiøb. 10 (1770): 537-618, here 538-39; Ioannes Sainovics, "Beviis, at Ungarernes og Lappernes Sprog er det samme: Oversat af det Latinske ved M.R. Fleischer," Skrifter Kiøb. 10 (1770): 653-732, here 731.

30 A likely model for Hell's work is the De litteraria expeditione by Boscovich and his fellow Jesuit Christopher Maire (1697-1767), published in 1755. As Boscovich explains in the preface, it consists of five parts: (1) a historical and physical account of the two Jesuits' expeditio litteraria through the Papal States, by Boscovich; (2) a determination of one degree of meridian on the basis of observations made by the two Jesuits, by Maire; (3) a correction of the geographical map of the Papal States, by Maire; (4) descriptions of the instruments used during the expedition, by Boscovich; and (5) a discussion of the shape of the Earth 
In the next part, ad Polum arcticum, "to" as a translation is obviously problematic: the North Pole was neither reached by Hell and his associates, nor was it ever meant to be. (Even though this is also what the German translation as Reisebeschreibung nach dem Nordpol implied. ${ }^{31}$ In this reading, "North Pole" simply designates "the region of the High North; the Arctic.") ${ }^{32}$ In reality, at most, they moved "toward" it, which the preposition $a d$, when connected with verbs or nouns implying movement, usually means. However, another frequent meaning of $a d$ is "by, near, in the vicinity of." This is the meaning one may infer from a manuscript covering magnetic observations made during the southbound part of the journey, that is, from Vardø toward Copenhagen. This manuscript bears the title "The Method Used for Observing the Magnetic Needle's Declinations during the Iter litterarium ad Polum boreum."33 (Iter, journey, is here a synonym for expeditio; boreus for arcticus.) Given the southbound travel route described in this manuscript, $a d$ is clearly meant on this occasion to imply "by the North Pole," not "toward." On these grounds, the sense of the expression Expeditio litteraria ad Polum arcticum is best conveyed as "Scientific Expedition by the North Pole."

Taken as a whole, the Expeditio litteraria was meant to comprise three volumes in folio, with numerous illustrations and several geographical maps of the regions visited by Hell and Sajnovics. One preserved portrait of Hell, produced in 1771, possibly with the intention of serving as additional promotional material for the Expeditio litteraria, shows the Viennese Jesuit flanked by the allegorical figures Religio and Scientia (see fig. 8). In the middle of the portrait, there is vivid imagery illustrating the delicate process of observing a transit of Venus. Even more conspicuous, however, are the books lying about underneath

on the basis of Newton's theory of gravity and the measurement of degrees, by Boscovich. Christopher Maire and Ruggiero Giuseppe Boscovich, De litteraria expeditione per Pontifciam Ditionem ad dimetiendos duos meridiani gradus et corrigendam mappam geographicam (Rome: Palladis, 1755), xiv. In 1770, this classic of geodesy appeared in a French edition, bearing the title Voyage astronomique et géographique, dans l'etat de l'eglise.

31 Maximilian Hell, Nachricht [...] Wien den 2. März 1771 (call for subscriptions, in German [n.p.: n.p.]), [1].

32 Such a translation is given by the editors in Andreas Christian Hviid, Andreas Christian Hviids Europa: Udtog af en Dagbog holden i Aarene 1777-1780 paa en Reise igennem Tyskland, Italien, Frankrige og Holland, ed. Michael Harbsmeier, Claus Mechlenborg, and Morten Petersen (Copenhagen: Forlaget Vandkunsten, 2005), 589n368: "En litterær ekspedisjon til de nordlige polaregne." In that interpretation, "Polus arcticus" would be a synonym for "Zona frigida arctica" (used by Hell in the call for subscriptions, Tomi II. Pars IV. Sectio I, see Aspaas, "Maximilianus Hell," 374-75).

33 Maximilian Hell, "Methodus observandi declinationes acus magneticæ per iter litterarium ad Polum boreum" (1769-70). wUs, Manuscripte Hell. 


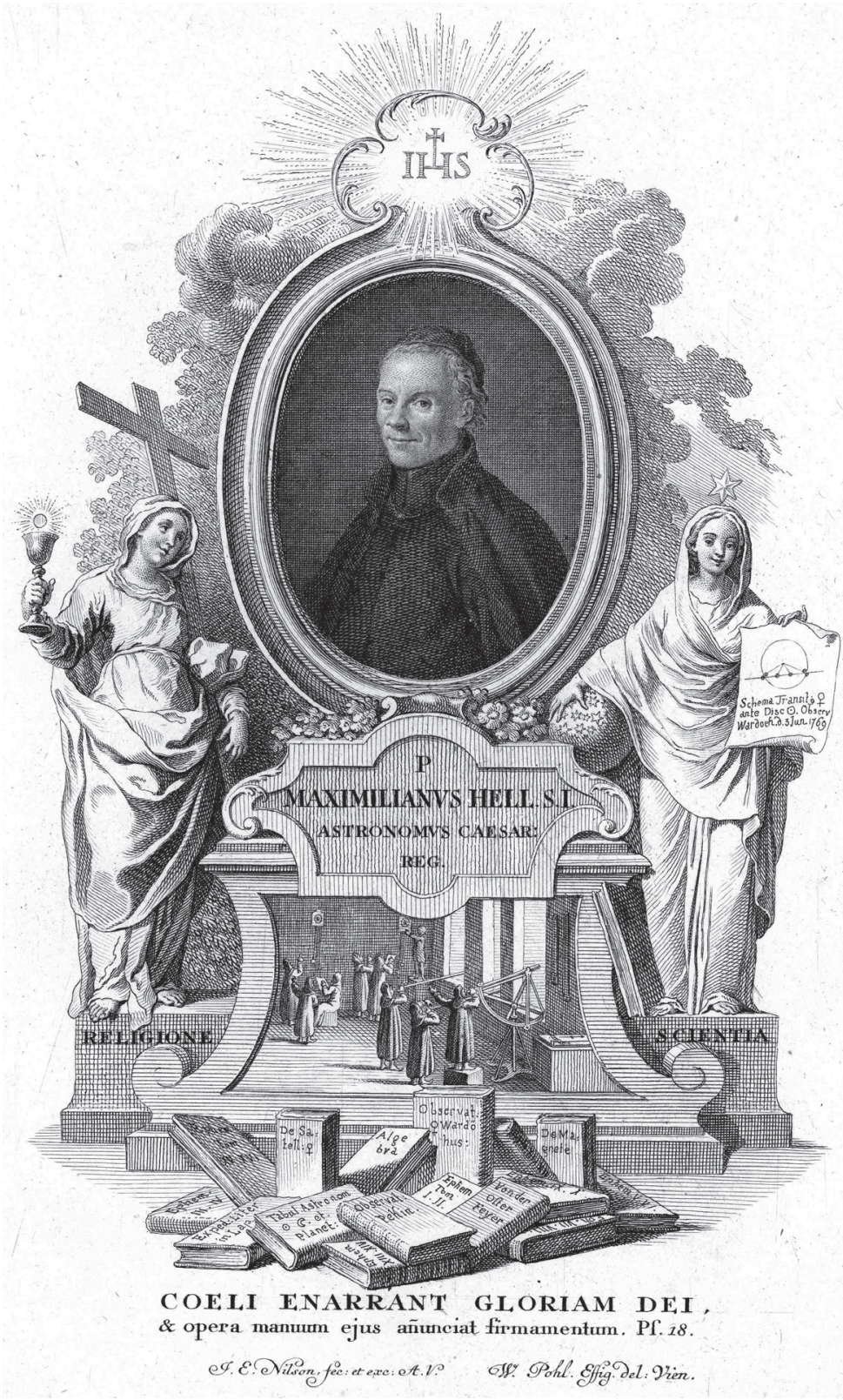

FIGURE 10 Maximilian Hell accompanied by his principal works and allegorical imagery Copperplate by the Augsburg miniature artist Johann Esaias Nilson (1721-88), based on a drawing by Wenzel Pohl (1720-90). Two versions of the copperplate exist. The earlier version lacks the "inscriptions" Religione and Scientia. These were, however, explicitly asked for by Hell, along with other minor changes in the extant drafts of two letters, undated and without explicit mention of recipients, but clearly addressed to Pohl and Nilson. Digitized by Nils Voje Johansen 
the portrayed Jesuit. Present among the titles are his report "Observat: 9 Wardöhus [...]" and the (never accomplished) "Expeditio litteraria" itself. Other titles are, besides various issues of the Ephemerides, the observations of Jesuit missionaries in China, edited by Hell (referred to as "Observat[iones] Pekin[enses]"), his Cluj textbooks on mathematics, his refutation of Schumacher's text on the Easter celebrations, his experiments with magnetism, his treatise on the moon of Venus as well as his tables of solar, lunar, and planetary orbits (here abbreviated "Algebra," "Von der Oster Feyer," "De Magnete," "De Satell[ite] \%," "Tabul[ae] Astron[omicae] $\odot \supset$ et Planet[arum]"). In other words, the court astronomer of Vienna is portrayed as a man who knows "everything." Above his head shines the radiant emblem of the Society of Jesus, with Religion and Science smilingly lending support to his endeavors: this sense emerges from the ablative case of the inscriptions, RELIGIONE and $S C I E N T I[\bar{A}]$, "by means of Religion and Science." The meaning of the allegory could hardly be missed. The metropolitan court astronomer had returned from the wilderness to civilization as an explorer with first-hand knowledge encompassing numerous branches of knowledge, backed by the Society of Jesus as a source of Enlightenment. Scherffer's worries are dispelled by this imagery, which supplies a resounding response to any critic of "Jesuits abusing the treasuries of kings."

\section{Enigmas of the Northern Sky and Earth}

The Expeditio litteraria was supposed to consist of three volumes, the second of which bore the title Tomus physicus. "Physics" here- true to the general understanding of the term in the eighteenth century-encompasses areas now known as meteorology and upper atmosphere physics, as well as natural history (marine and terrestrial biology alike), and even the exploitation of natural resources. In summary, the following parts were planned:

Part 1: On plants, animals, fish, etc. in northern Norway; Part 2: On the decrease of the sea level in the Far North; Part 3: On the luminescence of the sea in the Far North ("morild" in Norwegian); Part 4: A new theory of the Aurora Borealis; Part 5: Meteorological observations, including investigation of the ebb and flow of the tides, etc.; Part 6: Economic remarks. ${ }^{34}$

34 For a full edition and translation of the call for subscriptions, see Aspaas, "Maximilianus Hell," 361-81. 
Neither Hell nor Sajnovics could boast of a background as natural historians, and no article by them pertaining to the very first part of this volume ever saw the light of day. In research relating to natural history, they were no doubt aided by Borchgrevink who, it will be remembered, had been educated by Linnaeus at Uppsala. In a letter from Vardø to the professor of botany in Copenhagen, Georg Christian Oeder (1728-91), Hell promises to assemble "algae, mosses, and other aquatic plants" for Oeder to make use of for his purposes. ${ }^{35}$ Collecting plants of the Danish-Norwegian kingdom was now a priority, in conjunction with the richly illustrated Flora Danica, the first ten parts of which were edited by Oeder during this period. An alumnus of Albrecht von Haller (1708-77) at Göttingen University, Oeder himself had undertaken several expeditions across Denmark and Norway, but never traveled farther north than Rana in Nordland county, not too far beyond Trondheim.

What came out of Hell's promised contributions to the Flora Danica is, however, hard to establish, since Oeder was removed from office not long after Hell's return to Copenhagen, and the name of the collector of specimens for each plant is not mentioned in the printed Flora. Moreover, for this part of the Expeditio litteraria, Hell would probably have drawn heavily upon a pioneering work by bishop and amateur natural historian Erik Pontoppidan (1698-1764), the two-volume Norges Naturlige Historie (The natural history of Norway $\left.\left[175^{2-53}\right]\right)^{36}$ This richly illustrated work was also available in a German translation, to which Hell had access. ${ }^{37}$ Likewise, the two-volume work of another bishop, Gunnerus's Flora Norvegica (Norwegian flora $[1766-72])^{38}$ was likely to have been used as a consistent point of reference, along with various relevant articles in the proceedings of the Royal Society of Sciences in Trondheim, edited by Gunnerus and published in both Danish and an unabridged German

35 Hell to Oeder, dated Vardø, April 6, 1769 (wUs, draft): "Algas fucosque, cæterasque Plantas aquaticas."

36 Available in a facsimile edition, Erik Pontoppidan, Norges Naturlige Historie 1752-53 (Det første Forsøg paa Norges Naturlige Historie, forestillende Dette Kongeriges Luft, Grund, Fielde, Vande, Vexter, Metaller, Mineralier, Steen-Arter, Dyr, Fugle, Fiske og omsider Indbyggernes Naturel, samt Scedvaner og Levemaade), 2 vols. (Copenhagen: Rosenkilde og Bagger, facsimile 1977). An English edition was also published as The Natural History of Norway (London: A. Linde, 1755).

37 Erich Pontoppidan, Versuch einer natürlichen Historie von Norwegen, worinnen die Luft, Grund und Boden, Gewässer, Gewächse, Metalle, Mineralien, Steinarten, Thiere, Vögel, Fische und endlich das Naturel, wie auch die Gewohnheiten und Lebensarten der Einwohner dieses Königreichs beschrieben werden, trans. Johann Adolph Scheiben, 2 vols. (Copenhagen: Franz Christian Mumme, 1753-54).

38 Johan Ernst Gunnerus, Flora Norvegica: Observationibus praesertim oeconomicis panosque norvegici locupletata, 2 vols. (Trondheim: Typis Vindingianis, 1766-72). 
edition. In letters from Vardø, Hell shared some details of his observations in this domain; ${ }^{39}$ we may surmise that further details were communicated directly to the bishop by Borchgrevink. Hell also collected some specimens that were certainly delivered to Gunnerus, among them the littoral red algae then known as Fucus alatus and Ulva caprina, which "inhabits the sea of Finnmark, whence the highly famous astronomer, Mr. Prof. Hell, brought it to me, along with numerous other rarities from Finnmark," as Gunnerus recorded in the concluding volume of his Flora. ${ }^{40}$ Collections in the domain of zoology were exposed to unexpected hazards. In a letter from Vardø, Hell relates how

Sajnovics augments every day his collections of natural objects, but the mice of Vardø have dealt serious damage: all hermit crabs (a kind of small marine sea crayfish, living in mussels) that he so meticulously collected during our voyage and boiled red, have been completely eaten and destroyed by the mice. ${ }^{41}$

The second part of the Tomus physicus, on the decrease of the sea level in the Far North, was not published either. In an elaborate summary in the call for subscriptions, Hell promised to treat "signs and arguments in favor of the decrease of the sea level in the northern sea" and also to provide "geometric dimensions" of this development. ${ }^{42}$ In one of his manuscripts from Vardø, Hell took notes from a conversation with a thirty-year-old soldier at the fortress:

As a fifteen-year-old, he had seen with his own eyes how during high tide the water rose so high from the two bays that it became connected [i.e.,

39 Hell to Pilgram in Vienna, dated November 12, 1768; to Gunnerus in Trondheim, November 12, 1768; to Schöller in Trondheim, January 12, 1769; to Pilgram in Vienna, January 15, 1769; to Christian Horrebow in Copenhagen, January 15, 1769; to Gunnerus in Trondheim, January 15, 1769; to Mercier in Copenhagen, April 6, 1769; to Gunnerus in Trondheim, April 6, 1769; to Niebuhr in Copenhagen, April 6, 1769; to Öder in Copenhagen, April 6, 1769 (drafts for all letters are kept at wUs; many of them have been published by Pinzger, Hell Miksa, vol. 2).

$40 \quad$ Gunnerus, Flora Norvegica, 2:91, 2:127. The synonyms of the plants in modern taxonomy are Membranoptera alata and Palmaria palmata. Further evidence of sea algae and other plants that were delivered by Hell and Borchgrevink to Gunnerus can be found in Gunnerus's correspondence with von Linné. Johan Ernst Gunnerus and Carl von Linné, Brevveksling 1761-1772, ed. Leiv Amundsen (Oslo: Universitetsforlaget, 1976), 101-6.

41 Letter from Hell to Pilgram in Vienna, dated Vardø, January 15, 1769 (draft, wUs), parentheses are also found in the original. Printed in Pinzger, Hell Miksa, 2:50-55 (quotation on $53-54)$.

Hell, call for subscriptions, translation in Aspaas, "Maximilianus Hell," 373. 
cut the island into two halves]. This means that the sea level, during the fifteen years, has decreased as much as the current distance between the two bays. [...] The same soldier said that the winter cold intensifies more and more each year, an observation in perfect accordance with the decrease of the sea and rise of the land. [...] Perhaps the same decrease of the sea level is the cause of a general decrease in the amount of fish over the last decade, both in terms of the number of fish and their size. For when there is less water, there is obviously less fish as well. ${ }^{43}$

Based on this quick note, scribbled down at the spot, Hell took action. Before leaving Vardø for good in late June 1769, he made sure to erect two pillars at the highest level currently reached by the sea during high tide. The local clergy and military personnel were requested to keep an eye on the experiment by taking notes of how far the sea level receded from those pillars over the coming years. ${ }^{44}$ During stops on the southbound journey, he found further evidence in support of his conviction of a receding sea level. Such was the apparent speed of the development that Hell believed he could provide the world of learning with a discussion of "unavoidable politico-economical consequences resulting from the decrease of the sea level in the northern reigns." 45 Again, an enlightened perspective is adopted by Hell, in which natural knowledge has crucial implications for developments in the public domain, and the temporary servant of the Nordic kingdom does not hesitate to bring such implications to the attention of his masters and the wider world.

In the third part of the Tomus physicus, Hell promised to unveil one of the natural wonders of the north, namely the nightly luminescence of the sea, or "milky seas," known in the local Norwegian language as morild. The question of the cause of morild was a matter of dispute. In Pontoppidan's Norges Naturlige Historie, Hell seems to have read what the bishop had to say on the matter: according to an Italian study published in Venice, small "larvae" had been found to emit light when the water of the Mediterranean was stirred. These were, however, only visible when the sea water was sieved through a piece of cloth and the minuscule creatures thus trapped subsequently studied in a microscope ${ }^{46}$ A contradictory opinion was found in the first volume of the

\footnotetext{
43 Hell, manuscript beginning with the words "NB de horologijs" (wUs).

44 Kragemo, "Pater Hells Vardøhusekspedisjon," 118.

45 Hell, call for subscriptions, translation in Aspaas, "Maximilianus Hell," 373. An early stage discussion of this topic is found in Hell's letter to Niebuhr in Copenhagen, dated Vardø, April 6, 1769 (draft, wUs), incomplete transcript in Pinzger, Hell Miksa, 2:88-91 (on 90-91).

46 Pontoppidan, Norges Naturlige Historie, 1:117-20.
} 
proceedings of the Society of Sciences in Trondheim, where priest Erik Gerhard Schytte (1728-1808) reported from Lyngen, not far from Tromsø, that since in his experience "frozen sea water shines exactly like that which is not frozen," no "insects" could possibly be the cause of the light. Instead, he surmised that morild was caused by fragments of bitumen, which the soil in that area was teeming with. ${ }^{47}$ The question was subject to a great deal of attention by the Arabia Felix expedition as well. Although the natural history diaries of Niebuhr's associate, Pehr Forsskål (1732-63), had not yet been published, Hell may well have discussed the topic in his meetings with Niebuhr in Copenhagen during the northbound part of his journey. In any case, Forsskål was trying to find the cause of morild during the sea voyage soon after the expedition ship had left Copenhagen. Unable to find any trace of animals in the water samples, even when sieved through cloth as in the example from Venice, Forsskål concluded that the luminescence was probably caused by "the slimy residue of jellyfish." 48

During the dark winter nights of 1768 , Hell and his associates noticed that the Arctic Ocean sometimes proved to be luminescent. Accordingly, they took samples and performed tests similar to those described in Pontoppidan's book. They found—correctly— that the light in the sea around Vardø was caused by "quite small sea insects, no greater than an average flea, indeed far smaller than that" and visible only in the microscope. ${ }^{49}$ Hell describes his experiments in various letters from January $1769 .{ }^{50}$ In a particularly elaborate letter to Gunnerus, he confesses that earlier he had been convinced that morild was caused either by electricity or by pieces of minerals floating in the water, as argued by Schytte. However, when experimenting with the sea water in Vardø equipped with cloth, a microscope, and distillation apparatus, he managed to come to the conclusion that the tiny "sea insects" were the real cause of the phenomenon.

47 "Verschiedene Anmerkungen an den Bischoff in Drontheim," Der Drontheimischen Gesellschaft Schriften Erster Theil (1765), 242-49 (quotations on 249).

48 Lawrence J. Baack, Undying Curiosity: Carsten Niebuhr and the Royal Danish Expedition to Arabia (1761-1767) (Stuttgart: Franz Steiner, 2014), 96. See further, E. Newton Harvey, A History of Luminescence from the Earliest Times until 1900 (Philadelphia: American Philosophical Society, 1957), $5^{22}$.

49 Draft of letter from Hell to Gunnerus in Trondheim, dated Vardø, January 15, 1769 (wus; most of the letter is published in Pinzger, Hell Miksa, 1:59-62). In Norwegian waters, the cause of morild is usually species of the genera Noctiluca, Gonyaulax, or Ceratium, all animal planktons never exceeding two millimeters in size.

$50 \quad$ Hell to Schøller in Trondheim, dated January 12, 1769; to Pilgram in Vienna, dated January 15, 1769; to Horrebow in Copenhagen, January 15, 1769; to Peter Tønder Nordal in Trondheim, January 16, 1769 (all drafts, wUS). The investigations of the cause of morild are also mentioned in Sajnovics's travel diary, draft version (wUS), on December 9 and 10, 1768. 
In his letter to the bishop, he promised to submit an article on his findings to the proceedings of the Trondheim Society, ${ }^{51}$ but this came to nothing. Gunnerus, however, who cultivated frequent correspondence with von Linné in Uppsala, told the Swedish natural historian about Hell's findings and even made sure to have Hell send some specimens to Uppsala for inspection. ${ }^{52}$ The same happened to several botanical specimens: Hell brought dried plants with him to Denmark, from where they were carried farther to Uppsala. ${ }^{53}$ Thus, although his planned publications in the domain of natural history never saw the light of day, Hell's expedition program produced yields that contributed to the research of some of the most respected scholars in this domain.

Nothing of the sixth part, on the exploitation of natural resources, ever materialized. According to the call for subscriptions, it would present remarks on the migrations of the Sámi, including "observations concerning how to bring the migratory Lapps to lead a civilized life with stable dwellings." Temporary settlements and migrations across borders of the kind described in Sajnovics's notes from Tromsø, quoted above, were clearly recognized by the Viennese Jesuits as a central issue that exercised the minds of European "scientific travelers" across the world as well as the scholars who molded their accounts into comprehensive ethnographic works (whether under the label of global geography, global history, or otherwise). It is unfortunate that the findings of the Hell expedition did not find their way into this literature. Another problem that Hell promised to discuss was "the cause of the declining fishery in eastern parts of Finnmark," where the supply of salpa (cod, Gadus morhua) during the 1760 s had been so limited that it caused widespread poverty and even periodic starvation among the local population. ${ }^{54}$ With the benefit of hindsight, we can characterize this as fluctuations, whereas Hell and his informant appear to have interpreted the development as steady decline.

The fourth and fifth parts of the Tomus physicus, on the aurora borealis and on meteorological observations from Vardø, were in fact published, in the 1777

$51 \quad$ Draft of letter from Hell to Gunnerus in Trondheim, dated Vardø, January 15, 1769 (wUs). The promise is repeated in the Venus transit report: Hell, Observatio transitus [...] 1769, $2-3$.

52 Gunnerus to von Linné in Uppsala, dated Trondheim, September 2, 12, and [date not specified], 1769; von Linné to Gunnerus in Trondheim, dated Uppsala, October 5, 1769. Printed in Gunnerus and von Linné, Brevveksling 1761-1772, 101-6.

53 Gunnerus and von Linné, Brevveksling 1761-1772, 101-6.

54 Hell, call for subscriptions, in Aspaas, "Maximilianus Hell," 376-77. That there were meager quantities of cod caught in Vardø throughout the 1760 s is confirmed by the priest Henning Junghans Kaurin (1736-97), in his Jord Beskrivelse over Wardøe Prcestegield, og dets Tilstand fra 1764 til 1770 . Manuscript kept at NTNU Trondheim, University Library, Gunnerus XA Qv. 281. 
and the 1793 volumes of the Ephemerides, respectively. For centuries, the aurora had been one of the most intriguing riddles of the atmosphere, capable of spellbinding the general populace and scientific circles alike. Major theories of the eighteenth century included sulfurous emissions from volcanoes of the farthest north; reflections of the rays of the sun illuminating frozen particles in the upper atmosphere from underneath the horizon; discharges in the sky, either of a magnetic or electric nature (no theory of electromagnetism existed as yet); and a host of others. ${ }^{55}$ In his treatise, Hell refers to all the major theories in existence, refuting them one after the other. Notably, Hell dismisses a possible correlation between the northern lights and magnetism as well as electricity. Instead, the aurora borealis is described by him as a "purely optical phenomenon."

Hell had brought a kind of electric machine with him to Vardø to see whether there might be some way to measure the electricity involved in auroral outbreaks. Details regarding the instrument are not known, except that it was of English origin and had been borrowed from the senior district stipendiary of Christiania, the above-mentioned von Storm, an avid book collector who also took an interest in scientific experimentation. While in Vardø, Hell tested von Storm's electric machine in the period from October to January. ${ }^{56} \mathrm{He}$ found nothing, which is not surprising considering the extreme distance of the phenomena (it is now known that the average auroral outbreak takes place more than eighty kilometers above the surface of the Earth). As mentioned, Hell also had magnetic needles at his disposal, and in late April he set up a magnetic observatory to measure the fluctuations of the compass needle several times a day. He did experience some disturbances similar to those that had been reported by Anders Celsius (1701-44) and others. But when he looked up into the sky, there was no northern light in sight. What he did see, in the foggy conditions of the Vardø climate, was a variety of other optical phenomena, like rainbows, halos around the moon, and so-called parhelia, or "mock suns," all of which are purely optical illusions, which can sometimes resemble the aurora borealis. Accordingly, Hell vigorously rejected any connection between the

55 See, e.g., J. Morton Briggs, "Aurora and Enlightenment: Eighteenth-Century Explanations of the Aurora Borealis," Isis 58, no. 4 (1967): 491-503; Wilfried Schröder, Das Phänomen des Polarlichts (Darmstadt: Wissenschaftliche Buchgesellschaft, 1984); Per Pippin Aspaas, "The Auroral Zone versus the Zone of Learning: A Brief History of Early Modern Theories on the Aurora Borealis," in Travels in the North, ed. Silje Gaupseth, Marie-Theres Federhofer, and Per Pippin Aspaas (Hannover: Wehrhahn Verlag, 2013), 113-36.

$5^{6}$ Hell, "Aurorae borealis theoria nova," 8-9. Sajnovics, travel diary, proofread version (wUs), on July $16,1768$. 
northern light and magnetism or electricity, and concluded that it was a phenomenon of light being reflected in the atmosphere.

With the benefit of hindsight, we can conclude that Hell had set up his magnetic observatory far too late. In late April, May, and June, it is impossible to observe real aurorae because the sky is much too bright for that, even at midnight. Thus, the Midnight Sun blinded Hell's inquisitive eye. His conclusion was as follows:

The northern light is, therefore, a purely optical phenomenon in our atmosphere. It consists of frozen particles of moisture, of various shapes, most often flat, extremely smooth, and light, capable of densification as well as rarefaction. These particles float into the atmosphere at different distances from the Earth. They may be moved by any kind of movement in the air, for example, be tossed back and forth by winds. Furthermore, they can condense or disintegrate completely; in the manner of the lightest of clouds, they can be transported to various locations; heaped together into a thousand forms they exhibit different optic patterns, etc., etc. This light of the north is usually caused by the rays of the Sun, at other times, by the rays of the moon, or even by a combination of rays from the two celestial bodies simultaneously. The rays in question are reflected in the surface of the variously formed, frozen particles. Sometimes, the rays are both reflected and refracted simultaneously, depending on the conditions such as light, color, or the shape of the patterns. ${ }^{57}$

As mentioned, the conclusions of Hell's interesting, albeit mistaken Aurorae borealis theoria nova were presented as a lecture to the Royal Society of Copenhagen as early as March 1770. It was printed in Vienna in 1776, and a German translation, with rather extensive interpretative commentary in the preface by the editor, Hell's former student and professor in Breslau, Longinus Anton Jungnitz (1764-1831), appeared in $1792 .{ }^{58}$ Despite Hell's explicit comparison of his findings with the discoveries of Copernicus, ${ }^{59}$ his theory, even when published in full, hardly acquired any acclaim. Wargentin's associate, physicist Johan Carl Wilcke, immediately dismissed it, and nobody in Denmark-Norway appears to have embraced it; the academicians of Paris simply remained

57 Hell, "Aurorae borealis theoria nova," 79-80. Translation in Per Pippin Aspaas, "Biographical Introduction, Summary of Contents (manuscript version), Summary of Contents (Latin edition) and Summary of Contents (German edition)," Aurorae borealis studia classica 4 (2016): 1-17, here 12-13.

58 See Per Pippin Aspaas, "Biographical Introduction," 4, 14-17.

59 Hell, "Aurorae borealis theoria nova," 21-22. 
silent. ${ }^{60}$ The only part that was printed was the first and fundamental one, enunciating the theory in general with special emphasis on Hell's own observation data assembled north of the sixty-sixth latitude. In the further parts of the treatise, Hell promised to discuss auroral observations from more southerly latitudes. If finished, this would have brought him into an even more explicit confrontation with the leading theory in existence, that of Mairan. According to his Traité physique et historique de l'aurore boréale (Physical and historical treatise on the aurora borealis [1733, 2nd ed. 1754]), the phenomenon takes place when particles from the "atmosphere" of the Sun meet the atmosphere of the Earth. The reasons for Wilcke's dismissal may have been partly connected to the fact that two Swedes, Olof Hiorter (1696-1750) and Anders Celsius, had found the correlation between (genuine) auroral outbreaks and disturbances of the magnetic needle, which Hell rejected. ${ }^{61}$

Finally, as late as 1792, the year in which he died, Hell published his meteorological report from Vardøhus, Observationes meteorologicae in insula Maris Glacialis Wardoehus dicta (Meteorological observations made on the island of the Arctic Sea with the name of Vardøhus), originally intended as yet another part of volume $2 .{ }^{62}$ The weather report contains readings of barometers and thermometers (according to the scale of René Antoine Ferchault de Réaumur [1683-1757]) three times a day—at 7 a.m., 12 a.m., and 10 p.m. These readings were accompanied by a column designating "the appearance of the sky, weather, and directions of winds." This column contains brief notes on precipitation (not measured in quantity), wind directions, storms, and auroral outbreaks, from the mounting of the instruments on October 15, 1768 until their travel

6o Johan Carl Wilcke, Tal, om De nyaste Förklaringar öfver Norr-Skenet, hållet, i Kongl. Maj:ts höga nårvaro, för dess Vetenskaps-Academie (Stockholm: Johan Georg Lange, 1788), esp. $71-98$.

61 For a comprehensive discussion of this discovery and they way in which it was mediated in contemporary Sweden, see Sven Widmalm, "Auroral Research and the Character of Astronomy in Enlightenment Sweden," Acta borealia 29, no. 2 (2012): 137-56.

62 Maximilian Hell and János Sajnovics, "Observationes Meteorologicae in Insula Maris Glacialis Wardoehus dicta [...] factae 1768, et 1769," Ephemerides 1793 (1792), 352-93. This early series of meteorological observations seem to have escaped the notice of historians of meteorology in Norway. A brief series of data from 1829 to 1831 are mentioned as the earliest from Finnmark in B.J. Birkeland, "Ältere meteorologische Beobachtungen in Vardö," Geofysiske publikasjoner 10, no. 9 (1935): 1-52. Nor is Hell's meteorological report mentioned in Helge Kragemo, "Pater Hell's observasjoner i Vardøhus 1769," in Norvegica: Minneskrift til femti-årsdagen for opprettelsen av Universitetsbibliotekets norske avdeling 1883; 1. januar 1933 (Oslo: Grøndahl \& Søn, 1933), 220-26; Kragemo, "Pater Hells Vardøhusekspedisjon"; Kragemo, "Pater Hells ufullendte," in Med boken som bakgrunn: Festskrift til Harald L. Tveterås (Oslo: Tanum, 1968), 121-33. But see Lajos Bartha, "Hell Miksa légkörtani munkássága," Légkör 49, no. 4 (2004): 20-25. 
gear was packed down on June 23, 1769. Observations of aurorae are noted in a seemingly consistent manner in this column. As already described, according to Hell's theory, observation of northern lights during the Arctic night in May or June was perfectly logical. His theory comprised not only the aurora borealis as it is defined today but also other phenomena resembling it. Thus, on June 17 Hell noted: "Silent weather, but dark clouds, the sky growing more and more clear. Mediocre eastern wind, very clear sky with southern and southeastern wind continually alternating, until around 3 a.m., when northern lights disturbed the observations [emphasis added]." ${ }^{63}$ After the day-by-day, tabular overview with brief descriptions such as the one quoted here, there follows a seven-page commentary, Animadversiones, with descriptions of the instruments and methodology used, and-importantly—Hell's own deliberations on the weather conditions of Vardø. The very coldest recording, -18 Réaumur (corresponding to -22.5 Celsius), lasted for a very short time during the night between January 28 and 29 . However, the everyday winter temperatures fluctuated between 0 and -10 Réaumur (o to -13 Celsius) (i.e., perfectly comparable with the winter in Vienna). The existence of the Gulf Stream, constantly steering temperate sea water from the Bay of Mexico toward far-northern Scandinavia, was beyond the grasp of the Viennese visitor. Instead, he argued that the iceless waters around Vardø had resulted from a combination of three different factors, namely the nearly incessant waves of the sea, the general direction of the winds, and the currents pouring sweet water from the huge rivers of Russia. In Hell's view, the same three reasons contributed to the congelation of the vast expanse of sea from Novaya Zemlya to Spitsbergen and extending farther in an arch north of Iceland toward the shores of Greenland. All the while, the sea around Vardø remained open and free of ice:

Ice is never encountered by sailors on this Mare Glaciale [i.e., the Eismeer, nowadays officially the Barents Sea] when they are out in the open sea, several miles from the shore. However, as soon as they encounter great ice floes floating in the sea, the sailors know for sure that they are not far removed from the mainland. ${ }^{64}$

In sum, Hell's meteorological deliberations cast him in a typical Enlightenment role. On the one hand, we find Hell meticulously recording his endeavors, including inventing several creative solutions to gather data despite harsh winds threatening to tear their thermometers and other apparel to pieces. On the

63 Hell, "Observationes meteorologicae," 384.

64 Hell, "Observationes meteorologicae," 389. 
other, we find him assuming the role of interpreter of the Far North, synthesizing geophysical processes of global or at least circumpolar dimensions. Third, there is his application of knowledge to the benefit of sailors and decision-makers.

\section{On Hungarians and Laplanders ${ }^{65}$}

Having considered Hell's and Sajnovics's engagement with "nature in the north," the first volume of the Expeditio litteraria envisioned in the call for subscriptions needs attention. Apart from an introductory chapter by Hell, explaining how the expedition came about and the international context in which it was inscribed, this volume would certainly have relied heavily on contributions from Hell's assistant, Sajnovics. Its contents may be summarized thus: "Part 1: The history of the expedition, including a diary of the entire journey; Part 2: An ethnographic description of the 'Lapps'; Part 3: On the 'Lappish Language,' on its unity with the Hungarian language, and on the 'Asian Language' in general." Unlike Sajnovics's work on the Sámi language, epitomized in the Demonstratio and amounting to the third part of the first volume of the Expeditio litteraria as outlined in the call for subscriptions, the second part (which was to contain ethnographical descriptions of the Sámi) was never published. The preserved manuscripts are few, fragmentary, and insignificant compared with Hell's texts on Hungarian history and language. However, there is reason to suspect that this part would have consisted mainly in a summary of an original work by the Norwegian priest and Lappish-language professor, the author of the vocabulary used by Sajnovics and Hell during the expedition, Knud Leem (1697-1774): the chapter headings in Leem's bilingual, richly illustrated Beskrivelse over Finmarkens Lapper/De Lapponibus Finnmarchiae [...] commentatio (Description of the Lapps of Finnmark [1767]) match the chapters planned by Hell quite well. ${ }^{66} \mathrm{~A}$ few comments would probably have been

65 We have addressed aspects of the topic of this section in Per Pippin Aspaas and László Kontler, "Before and After 1773: Central European Jesuits, the Politics of Language, and Discourses of Identity in the Late Eighteenth-Century Habsburg Monarchy," in Latin at the Crossroads of Identity: The Evolution of Linguistic Nationalism in the Kingdom of Hungary, ed. Gábor Almási and Lav Subarić (Leiden: Brill, 2015), 95-118.

66 Available in a facsimile edition, Knud (Canutus) Leem, Beskrivelse over Finmarkens Lapper 1767, Efterord af Asbjørn Nesheim (Knud Leems, Professor i det Lappiske Sprog, Beskrivelse over Finmarkens Lapper, deres Tungemaal, Levemaade og forrige Afgudsdyrkelse, oplyst ved mange Kaaberstykker: Med J.E. Gunneri [...] Anmarkninger; Og E.J.Jessen-S. [...] Afhandling om de Norske Finners og Lappers Hedenske Religion/Canuti Leemii, professoris lingvee 
added by Hell, based on his Lapland experiences, but one may assume that this part of the Expeditio litteraria would have relied mostly on Leem's work.

Sajnovics, who was the author of the "diary of the entire journey," had spent the last couple of years as an assistant of Weiss at the Trnava observatory by the time Hell received an invitation from Copenhagen, so he may not have been the likeliest candidate for the role of Hell's companion on the journey. In the unfinished draft introduction to the Expeditio litteraria, Hell states the obvious, namely that Sajnovics was chosen because of his likable personality, his good health, and his astronomical skills. An alternative or supplementary explanation also lends itself: on his own testimony, Sajnovics was "born and raised in Hungary by Hungarian parents." ${ }^{67}$ As one of the principal sub-projects associated with the Vardø expedition (to be elaborated in part 3 of volume 1) was the investigation of the linguistic kinship between Sámi and Hungarian, having a member of the crew with Hungarian as his mother tongue was certainly of some significance. It is, however, hard to corroborate the claim that Hell judged Sajnovics's linguistic skills to be of importance already in 1767 . There is counter-evidence to suggest that the idea of such an investigation may have been formed at a later stage, almost by hazard. Before we investigate this possibility, a brief sketch of the "pre-history" of Finno-Ugrian comparative linguistics seems warranted.

Although neither the notion of "language families" nor the term "FinnoUgrian" (or Finno-Ugric) existed before the nineteenth century, by itself, the positing of the kinship of Hungarian and Sámi was nothing new at the time of the expedition. ${ }^{68}$ One of the earliest academic texts arguing for a linguistic link between several of the languages now considered Finno-Ugrian was written by Martin Fogel(ius) (1634-75) of Hamburg, De Finnicae linguae indole

Lapponice, de Lapponibus Finmarchice, Eorumqve lingva, vita et religione pristina commentatio, multis tabulis ceneis illustrata: Una cum J.E. Gunneri [...] Notis; \& E.J.Jessen-S. [...] Tractatu singulari de Finnorum Lapponumqve Norvegic. religione pagana) (Copenhagen: Rosenkilde og Bagger International Boghandel, 1975). Cf. the chapter headings with Hell's call for subscriptions.

67 János Sajnovics, Demonstratio: Idioma Ungarorum et Lapponum idem esse (Copenhagen: Salicath, 1770) and (Trnava: Collegium Academicum Societatis Jesu, 1771), [x]. For modern editions, see the facsimile, ed. Thomas A. Sebeők (The Hague: Mouton, 1968); German translation by Monika Ehlers, Beweis, das die Sprache der Ungarn und Lappen dieselbe ist, ed. Gyula Decsy and Wolfgang Veenker (Wiesbaden: Harrassowitz, 1972); Hungarian translation by Zsuzsa C. Vladár, Demonstratio: Bizonyitás; A magyar és a lapp nyelv azonos, ed. Enikő Szíj (Budapest: ELTE, 1994).

68 For a standard narrative of the early modern roots of Finno-Ugrian linguistics, see Günter Johannes Stipa, Finnisch-ugrische Sprachforschung: Von der Renaissance bis zum Neupositivismus (Helsinki: Suomalais-ugrilainen Seura, 1990). 
observationes (Notes on the character of the Finnic language), whose manuscript from 1669 was later unearthed among the papers of Gottfried Wilhelm Leibniz (1646-1716). ${ }^{69}$ The works that Leibniz and his collaborator, Johann Georg von Eckhart (1664-1730), put forward in the early eighteenth century became seminal. Leibniz argued for the large-scale collection of samples from various vernaculars, not least in Russia. In this context, he pointed to a supposed connection between Sámi, Finnish, Hungarian, and several indigenous languages found in the Russian realm..$^{70}$ Collection of linguistic data from Russia, however, did not begin in earnest until the 1720s. Several expeditions were then dispatched to chart the Russian Empire, with linguistic studies forming part of the research programs. A German-speaking Swedish officer who had been taken captive and sent to Siberia, Philipp Johann von Strahlenberg (16761747), took part in one of the earliest expeditions. After being released, he published a sensational book on the northern and eastern parts of Russia (1730). ${ }^{71}$ In his book, von Strahlenberg included a table with words from what he defined as "the Tatarian and Hunno-Scythian ancestral peoples." All the languages he included in the table are now considered parts of the Uralic language family, in which the Finno-Ugrian group (or, as he called it, the "Hun nation") constitutes the largest branch. Mutatis mutandis, von Strahlenberg perceived the linguistic links between the entire group of Finno-Ugrian peoples, with members from Siberia (Mansi, Khanty) via northwest Russia (Komi, Mari, Mordvin, etc.) and the Baltics (Estonian, Livonian) to Central Europe (Magyar) and Fennoscandinavia (Sámi, Finnish, Karelian). ${ }^{72}$

Further contributions in the same vein as von Strahlenberg added more empirical material besides presenting theories on the ethnic kinship of the Magyars. They include several works by Johann Eberhard Fischer (1697-1771), who was the secretary of the second Kamchatka (or "Bering") expedition between 1733 and 1743 (himself involved in the fieldwork from 1740): De origine

69 On Fogel, see Maria Marten and Carola Piepenbring-Thomas, Fogels Ordnungen: Aus der Werkstatt des Hamburger Mediziners Martin Fogel (1634-1675) (Frankfurt am Main: Vittorio Klostermann, 2015).

70 Gottfried Wilhelm Leibniz, "Brevis designatio meditationum de Originibus Gentium, ductis potissimum ex indicio linguarum," Miscellanea Berolinensia ad incrementum scientiarum, ex scriptis Societati Regiae Scientiarum exhibitis edita 1 (1710): 1-16; cf. Stipa, Finnisch-ugrische Sprachforschung, 155-64; Hans Arens, Sprachwissenschaft: Der Gang ihrer Entwicklung von der Antike bis zur Gegenwart (Freiburg: K. Alber, 1969), 94-104.

71 P.J. [Philipp Johann] von Strahlenberg, Das Nord- und Ostliche Theil von Europa und Asia, Jn so weit solches Das gantze Rußische Reich mit Siberien und der grossen Tatarey in sich begreiffet [...] (Stockholm: In Verlegung des Autoris, 1730).

72 Modern archival studies have revealed that his book relied heavily on materials collected by another participant of the same expedition, Daniel Gottlieb Messerschmidt (16851735). See Stipa, Finnisch-ugrische Sprachforschung, 173-79. 
Ungarorum (The origin of Hungarians, written in 1756, and published as part of a more comprehensive work in 1770), and the two-volume Sibirische Geschichte von der Entdeckung Sibiriens bis auf die Eroberung dieses Landes durch die Russische Waffen (Siberian history from the discovery of Siberia to the conquest of this land by Russian arms [St. Petersburg, 1768]). Fischer's books reiterated the claim that the Hungarians are a Finno-Ugrian people, and soon became reference works in German academic circles, particularly in Göttingen, where the theory became enshrined in August Ludwig von Schlözer's (1735-1809) widely influential Allgemeine nordische Geschichte (General Nordic history [1771]).73 In Hungary itself, the first to embrace the Finno-Ugrian theory was the remarkable Lutheran antiquarian scholar Dávid Czvittinger (1675/79-1743) in his Specimen Hungariae litteratae (Sample of Hungarian learning [1711]). There were several others to prepare the ground for Sajnovics, including individuals who did so despite their uneasiness with the theory, such as Bél, who presumed to identify the remnants of the "Hungarian-Scythian" language in Finnish. ${ }^{74}$ One also finds brief mentions of hypotheses of linguistic kinship of the same kind in several ethnographic and geographic works, such as Johannes Schefferus's (1621-79) classic monograph Lapponia $(1673)^{75}$ or the influential Erdbeschreibung (Description of the world [1764-92]) by Anton Friedrich Büsching $(1724-93) \cdot^{76}$

73 Fischer's role is usually understood as subsidiary to the better-known German scholars recruited for the expedition, naturalist Johann Georg Gmelin (1709-55) and especially historian Gerhard Friedrich Müller. He is also recognized as having written at the request of von Schlözer the Vocabularium Sibiricum (1747), deposited in manuscript as a gift in the Historical Institute in Göttingen, to be used extensively by later scholars there. The literature on Fischer is meager, but see passing references in Yuri Slezkine, "Naturalists versus Nations: 18th-Century Russian Scholars Confront Ethnic Diversity," Representations, special issue, "National Cultures before Nationalism," 47 (Summer 1994): 170-95, here 186-87; in more detail, Vermeulen, "Anthropology in Colonial Contexts," 22-25; and Vermeulen, Before Boas, 167-71, 186-94, 281, 294. For the Kamchatka expeditions in the context of eighteenth-century Russian voyages of discovery, see Erich Donnert, Russia in the Age of Enlightenment (Leipzig: Edition Leipzig, 1986, German original 1983), 95-114.

74 Péter Domokos, Szkittiától Lappóniáig: A nyelvrokonság és az őstörténet kérdéskörének visszhangja (Budapest: Universitas, 1998).

75 Johannes Schefferus, Lapponia, id est regionis Lapponum et gentis nova et verissima descriptio (Frankfurt: Ex officina Christiani Wolffii, 1673), esp. 177-83 (a chapter consisting primarily of a comparison between Sámi and Finnish, which are indeed related languages). The book was also made available in German, English, French, and Dutch editions between 1674 and 1682 .

76 Anton Friedrich Büsching, Neue Erdbeschreibung (Hamburg: Bohn, 1764), e.g., 1:428: "Their [the Finnish] language is slightly different from the Estonian, in dialect only; furthermore, it is related to Lapponian and in some respects to Hungarian as well." 


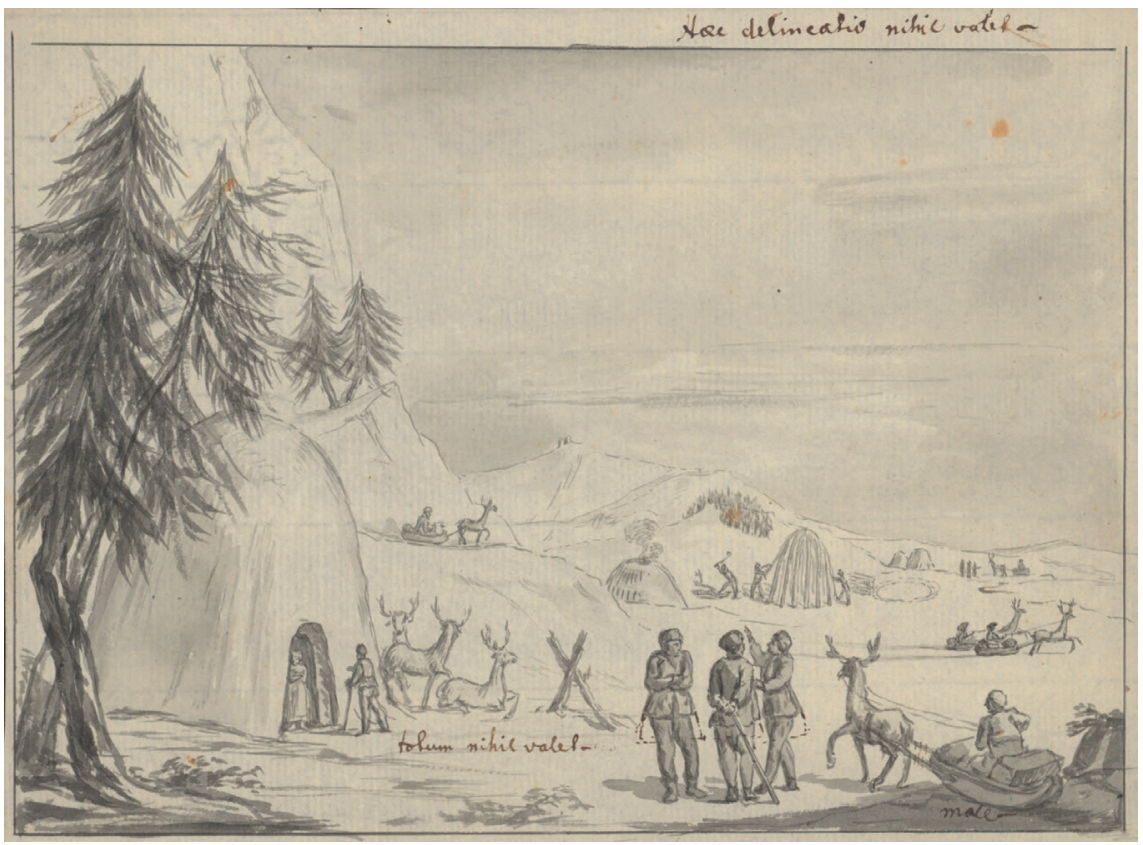

FIGURE 11 Sámi community

Drawing clearly commissioned by Hell, with annotations in his hand. The annotations translate as "bad," "all this will not do," and "this entire drawing is worthless." Digitized by the Department of Astrophysics, University of Vienna

As Sajnovics's travel diary testifies, already at the stations of the northward journey he was paying attention to the lifestyle and the customs of the locals of the region, and the topic was also discussed (together with the observations of the flora and fauna and collecting of natural specimens) in the reports published in the Viennese press during the team's sojourn in Vardø. ${ }^{77}$ Using local priests and missionaries as intermediaries, during these nine months Sajnovics had ample opportunities to pursue linguistic fieldwork among the Sámi. He summarized the results in three lectures to the Copenhagen academy at the beginning of 1770 , and published them in the same year while still in the Danish capital as the Demonstratio Idioma Ungarorum et Lapponum idem esse (Demonstration that the language of the Hungarians and the Lapps is the same). A revised edition, leaving the original text virtually unchanged but supplementing it with important elements, appeared in Trnava in the following year. Already in the 1770 s and 1780 s, the Demonstratio attracted considerable 
attention ${ }^{78}$ and received further reinforcement from the publication of the $A f$ finitas linguae Hungaricae cum linguis Fennicae originis grammatice demonstrata (Grammatical proof of the affinity of the Hungarian language with languages of Fennic origin [1799]), written in Göttingen with von Schlözer's patronage by the Transylvanian physician and linguist Sámuel Gyarmathi $\left(175^{1-1830}\right)$. Today, the value of these two works is recognized to consist in going beyond the predecessors mentioned above in their systematic application of the principles of linguistic comparison to their data-in the case of Sajnovics, gained from first-hand empirical work - and their emphasis on evidence not just from vocabulary, phonetics, and phonology but also grammatical structures.

Rather than venturing a detailed analysis of the linguistic contribution of the Demonstratio here, ${ }^{79}$ the question of authorship in strict and broader terms merits attention. This is not because of antiquarian issues of attribution, but because it is closely related to the larger problem of Hell's development of new academic agendas, including the origin and early history of the Hungarians, which in turn became highly relevant to his position in the public-political landscape of the Habsburg monarchy in the wake of the suppression of the Society of Jesus in 1773 .

In the first, Copenhagen edition of the Demonstratio, Hell is acknowledged for having asked Sajnovics to undertake this research, for pointing out certain methodological guidelines for his assistant's interviews with native Sámi speakers, and for never allowing him to give up, even though the task proved difficult. The second, Trnava edition, goes much further. As to the reason for electing Sajnovics as travel companion, the following statement is found in the slightly rephrased introduction to the second edition:

For he [Hell], with the same benevolence that he had bestowed upon me already some time ago, during that two-year period when he wanted me to assist him in his astronomical tasks in Vienna, had chosen me also for this expedition to the Far North, and brought me along to Finnmark as a travel companion and an assistant in his activities, in particular in his endeavors to investigate the Lappish language. This was an occasion for Hungarians to visit the Lapps, this was an occasion to test the conjecture of a

78 The Copenhagen edition had already been extensively reviewed (a mere two months after its publication) in the GAgS [18]:1, no. 78 (June 30, 1770): 674-79. The Journal des Sçavans also reported on it, see JS (February 1772): 121.

79 For an excellent assessment in English along the lines indicated above, see Zsuzsa C. Vladár, "Sajnovics's Demonstratio and Gyarmathi's Affinitas: Terminology and Methodology," Acta linguistica Hungarica 55, nos. 1-2 (2008): 145-81. 
correlation between the Hungarian and Lappish language, which Honorable Father Hell had formed in his mind already beforehand, from reading the "Lapponia" of Schefferus and the "Geographia" of Büsching, a conjecture he had mentioned to me every so often during the journey [emphasis added]. ${ }^{80}$

Hell now appears explicitly as not merely a constant source of support but as the fons et origo of the linguistic endeavor of the Vardø expedition. His direct involvement in the project is also stressed by changing "an occasion for a Hungarian [Ungaro] to visit the Lapps" in the first edition to the plural (Ungaris) in the second. An extant draft in Hell's own hand, intended to be sent to Sajnovics in the winter of $177^{-}-71$, demonstrates that these changes were introduced in the Trnava edition upon Hell's own explicit instruction:

In the preface to the Royal Society [of Copenhagen] // After the words: "Imperial and Royal Astronomer from the University of Vienna" [add the following], "also a Hungarian by nation, invited to Vardøhus by the redoubtable Majesty King Christian VII of Denmark and Norway in order to observe the transit of Venus in front of the disc of the Sun. Since the same Hell, formerly my teacher in astronomical subjects, had chosen me as his travel companion in order to assist him in his astronomical tasks and in particular the examination of the Lappish language, I set off for Finnmark, where I spent about a year. // For on this occasion, it was possible for Hungarians to spend time among the Lapps; on this occasion, it was possible to put to the test Father Hell's conjecture, which he based upon the Geographia of Büsching and the Lapponia of Schefferus and which he had frequently mentioned to me during the journey $[\ldots] . "{ }^{\prime 1}$

As a result of the additions and the small amendments in the second edition, Hell emerges as not only the initiator but the permanent guiding spirit of and an equal, even principal contributor to the research. He now appears also to have been the one who introduced Sajnovics to the method of comparison: "In his leisure hours, he joined me, studied the Nomenclator [the 1756 Danish-Lappish dictionary of Leem] with me, searched for words and interpreted them."82 He is credited with having directed the work of data collection by putting

\footnotetext{
$80 \quad$ Sajnovics, Demonstratio (1771), [xi-xii], cf. 22.

81 "In adlocutione ad Societatem Regiam," Manuscripte Hell, wus. Digitized in Aspaas, "Maximilianus Hell," 126-7.

82 Sajnovics, Demonstratio (1771), 23.
} 
together the list of questions to be asked during the interviews with the natives, ${ }^{83}$ and he even took the initiative personally: while engaged in a long conversation about the Sámi with a missionary named Daas, a "Karelian" fisherman entered the house, and it was upon Hell's explicit instruction that he was requested to recite the Pater noster in his mother tongue. ${ }^{84}$

The idea of listening to spoken "Karelian" (related as it is to both Finnish and Sámi) and thus recognizing similarities in phonological structures may well have been Hell's. However, the story of Hell's planning the investigation and framing the methodology is hard to reconcile with other pieces of evidence. The above-mentioned Nomenclator as well as a Grammatica, or Lappish grammar, by professor of the Sámi language Knud Leem was given to the company by von Storm in Christiania during their northbound trip, "as a token of great friendship, without us asking for this at all," Sajnovics explains. ${ }^{85}$ A couple of weeks later, Hell and Sajnovics landed in Trondheim, where they spent three weeks preparing the continuation of their expedition. Trondheim was the place where Leem lived and worked, as professor of the Seminarium Lapponicum, or special seminary giving language instruction to Norwegians preparing for a career as missionaries in the northernmost parts of the kingdom..$^{86}$ It is here that the narrative of a "planned discovery" of the linguistic link between Sámi and Hungarian, and thereby also between "Lapps" and "Magyars," falters. ${ }^{87}$ Assuming that this kind of research was at the top of Hell's priorities, it seems

83 Sajnovics, Demonstratio (1771), 24.

84 Sajnovics, Demonstratio (1771), 22-23; an account of this incident is found in the first edition as well, but without mention of any role played by Hell, Demonstratio (1770), 14-15. "Karelian" is one of several ethnonyms formerly used for the group now commonly known as Kven, i.e., people that migrated from Finnish-speaking parts of modern Finland and northern Sweden to settle along the coast of northernmost Norway during the early modern period. The form of Finnish spoken by Kvens deviates slightly from the official language in Finland, and since 2005 Kven has been formally recognized a minority language in Norway.

85 Sajnovics, Demonstratio (1770), 15; Demonstratio (1771), 23; travel diary, proofread version (wUs), on July 16,1768 .

86 Dedicated missionary work in Dano-Norwegian Lapland began early in the eighteenth century, motivated not only by pietistic ideals associated with the saving of souls but also by a perceived need of transforming the migratory Sámi into loyal subjects of the DanoNorwegian state. Cf. Jan Ragnar Hagland and Steinar Supphellen, eds., Knud Leem og det samiske, Det kongelige norske videnskabers selskabs Skrifter (Trondheim: Tapir akademisk, 2003).

87 It has already been suggested that the investigation of the Sámi language and its affinity with Hungarian, with all the implications to Hungarian prehistory, was an improvisation of the expeditionists while already en route to Vardø in Lajos Bartha, "Sajnovics János, Hell Miksa és a 'magyar őstörténet," Nyelvtudományi Közlemények 85 (1983): 297-304. 
strange that there is no mention at all of an attempt to contact the main authority on Sámi language and ethnography in the country during their threeweek stay in Trondheim. Other factors that may point to the improvised character of the linguistic research of the expedition include Sajnovics's enthusiastic mention of having been supplied with a copy of the famous Nova grammatica Ungarica (New Hungarian grammar [1610]) of Albert Szenczi Molnár (15741634) during the southbound stay in Copenhagen: had there been a preconceived intention to inquire into the subject, this book ought to have been an almost mandatory item in the Jesuits' luggage. It might be added that, besides this work, the only Hungarian grammar referenced in the Demonstratio is the standard Jesuit grammar by Pereszlényi, mentioned above. ${ }^{88}$ One would also have expected Hell to have already asked for the most recent literature on the Sámi language and ethnography while in Copenhagen, with the Royal Library and the avid collector of learned literature and mighty interior minister Thott close at hand. 89

Throughout their stay in Denmark-Norway, Hell and Sajnovics enjoyed Thott's support. It is in this connection that the idea of introducing Hungarian orthography into the Sámi language, as a fully new topic in the 1771 edition of the Demonstratio also ascribed there to Hell, merits separate mention. ${ }^{90}$ This had important, though short-lived resonances in Copenhagen: by Thott's decision, the recommendations of the Viennese visitors were to be followed in the revision and reissuing of the official Danish dictionary of the Sámi language. In doing so, Thott overruled protests from Norwegian priests and missionaries who had a different understanding of the Sámi language and its origins. ${ }^{91}$ The

88 Sajnovics, Demonstratio (1770), 82: "Alone Molnár's words, full of perspicuity and honesty that they are, are found worthy of being quoted. He [...] wrote a grammar of Hungarian, published in Hanover and not seen by me until it was communicated to me by the Illustrious Gentleman Langebeck [...]"; repeated in 2nd ed. (1771), 130. We are grateful to Zsuzsa C. Vladár for having called our attention to the scarce reliance on Hungarian grammars in the Demonstratio.

89 There is no record of an (attempted) meeting with Leem in 1768 . However, the diary for the southbound journey contains the brief statement that "Mr. Leem, professor of the Lapponic language was visited." Sajnovics, travel diary, draft version (wUs), on September 7,1769 .

$90 \quad$ Sajnovics, Demonstratio (1771), 33.

91 This story is recounted in detail by Bente Martinussen, "Anders Porsanger: Teolog og språkforsker fra 1700-tallets Finnmark," Nordlyd 18 (1992): 15-59; for a brief English summary of her conclusions, see Even Hovdhaugen et al., The History of Linguistics in the Nordic Countries (Helsinki: Societas Scientiarum Fennica, 2000), 54-55. See also Pekka Sammalahti, "History of Finno-Ugric Linguistics in the Nordic Countries," in Studies in the Development of Linguistics in Denmark, Finland, Iceland, Norway, and Sweden, ed. Carol Henriksen et al. (Oslo: Novus Forlag), 297-323; Per Pippin Aspaas, "Maximilian Hellin ja 
"Royal stamp" that protected Hell and Sajnovics while in Denmark-Norway also secured them collaboration from virtually every core member of the Royal Society of Copenhagen. This is evident from the concluding chapter of Sajnovics's Demonstratio, where numerous savants who had contributed to his studies by lending him books and offering other sorts of assistance are singled out and thanked. Not surprisingly, Thott was the dedicatee of both editions of the Demonstratio. In December 1770, however, in the aftermath of a coup staged by Christian viI's personal physician Johann Friedrich Struensee (1737-72), Thott was forced to resign from all his offices. ${ }^{92}$ By the time the orthographic reform was propagated in the second edition of the Demonstratio, the initiative had lost its chief patron in Copenhagen, and was dropped.

Finally, frequent anticipations of the Expeditio litteraria also serve to associate the Demonstratio more closely with Hell. A newly introduced sentence by Sajnovics in the 1771 edition is either an innocently polite gesture toward the strong man of the expedition, or an all too unconcealed acknowledgment of the ongoing process of appropriation: "Reverend Father Hell is treating the present little work with benevolence, as if it were his own [italics added] and will publish it for the third time inserted in his Expeditio litteraria." ${ }^{\prime 93}$ The 1771 edition also contains specific information about some of the planned content of the larger work, and a part of this, again, can be traced back to direct instruction by Hell, this time in another draft, also to be sent to Sajnovics in Trnava during the winter of $170^{-}-71$ :

Moreover, in the same work (as I learned from the same letter of Father Hell's, recently sent to me from Vienna), he will not only demonstrate the common origin of each of the two peoples, that is, the Hungarians and the Lapps; he will also, by means of weighty evidence, show that the Fenni, or Finns, are the ancestors of all the various tribes that use the Hungarian language, and especially that the ancient fatherland of that most noble Hungarian tribe, which inhabits Hungary, was Carjelia, and that

Johannes Sajnovicsin 'Expeditio litteraria ad Polum arcticum' ja suomalais-ugrilaisen kielentutkimuksen synty," in Lapin tuhat tarinaa, ed. Osmo Pekonen and Johan Stén (Ranua: Mäntykustannus, 2012), 65-86.

92 The same happened to another supporter of the two Jesuits, the foreign minister Bernstorff. It seems Struensee's coup even brought an end to Danish participation in projects of international science; cf. Allan Sortkær, "Hvilken fortræffelig gave fra den danske nation til videnskaben! Fremkomsten af internationale videnskabelige ekspeditioner i 170o-tallet," Den Jyske Historiker, special issue, "Danske Videnskabelige Ekspeditioner," 119 (2008): 5-25, esp. 21-23.

93 Sajnovics, Demonstratio (1771), 55 . 
the Carjelians are the genuine ancestors of the Magyars and Hungarians $[\ldots] .{ }^{94}$

Like this one, each of the other anticipations of the contents of the Expeditio litteraria in the 1771 edition of the Demonstratio concerned issues broadly related to the larger problem of the origins, including the original home, of the Hungarians. Hell's interaction with the eminent Jesuit historian Pray, who dedicated a great deal of attention to the same issues in the same period, sheds interesting light both on the development of his own ideas on the subject, and his understanding of his role in the linguistic achievement of the Demonstratio. ${ }^{95}$

One of the relevant passages of the 1771 edition discusses the origin of Hungarians, Sámi, Finns, and so on from "the neighborhood of China."96 This resonated in complex ways with the argument put forward in Pray's Annales veteres Hunnorum, Avarum et Hungarorum (Ancient annals of the Huns, Avars, and Hungarians [Vienna, 1761]), where the recent proposition by the French orientalist Joseph de Guignes (1721-1800) in his Histoire générale des Huns, des Turcs, des Mongols, et des autres peuples Tartares occidentaux (General history of the Huns, Turks, Mongols and other western Tartar peoples [1756-58]) that the Hsiung-nu mentioned in ancient Chinese sources were identical with the Huns, was combined with the older theory of Hun-Hungarian kinship. ${ }^{97}$ The idea of a prestigious steppe kinship of the Hungarians with the mighty Huns had been the standard narrative of the subject matter ever since the early Middle Ages. It was incorporated in the Gesta Hungarorum (Deeds of the Hungarians) of the obscure twelfth-century royal notary Anonymus, whose account of the ninth-century "reconquest" of the territory of the future Kingdom of Hungary by the Magyar descendants of the people of Attila became the basis of a full-fledged social and political ideology of the Hungarian nobility in a work written in $1282-85$ by Simon Kézai (Simon of Kéza), bearing the same title. Kézai proposed that the nobility's social pre-eminence, privileges, and political

94 Sajnovics, Demonstratio (1771), 119. Cf. "Jn eo autem opere [...]," Manuscripte Hell, wus.

95 For an analysis of these connections from the perspective of linguistics, see Zsuzsa C. Vladár, “Valójában ki a szerzője a Demonstrációnak?," Magyar Nyelv 112, no. 3 (2016): 31624; Vladár, "Hell mint nyelvész: A Kar-jelia etimológia és a kínai hasonlítás példája," in $A$ nyelvtörténeti kutatások újabb eredményei , ed. Tamás Forgács, Miklós Németh, and Balázs Sinkovics (Szeged: SzTE, 2017), 9:337-50.

96 Sajnovics, Demonstratio (1771), 50-51.

97 On the "discovery of Eurasia" by de Guignes, see J.G.A. Pocock, Barbarism and Religion, vol. 4, Barbarians, Savages, and Empires (Cambridge: Cambridge University Press, 2005), 99-155. 
rights derived from the military prowess demonstrated by their ancestors in the taking of the land, and that a sort of politia commixta, the proper form of government already among Attila and the Huns, was also preserved among their Hungarian offspring. The two works were first printed in 1746 and 1781 , respectively, ${ }^{98}$ a period in which this theory (perpetuated by several later medieval and humanist chronicles and the most frequently printed Hungarian book of all time: the 1517 Tripartitum, a collection of customary law by jurist and statesman István Werbőczy [1458-1541 ${ }^{99}$ ) still held considerable authority. ${ }^{100}$ While Anonymus was edited by the Protestant Bél and his disciple Johann Georg Schwandtner (1716-91), and Kézai by the Piarist erudite Elek Horányi (1736-1809), it is noteworthy that—as Pray's work signals—-historical interest among Hungary's Jesuits was turning from questions of chronology and dynastic issues to problems central to discourses of identity shortly before the time Hell and Sajnovics formulated their ideas on Hungarian-Sámi (language) kinship.

We shall consider the predominantly hostile reaction of the adherents of the "Scythian" theory to their proposition in Chapter 8, in connection with the chances of Hell finding new social allies after the suppression of the Society of Jesus by reconfiguring himself as a Hungarus patriot. What is important to note here is that the efforts in the "domestic" (Trnava) edition of the Demonstratio to tacitly forge a link for the Sámi and the Hungarians with the Huns by tracing their languages back to Chinese (supposedly the source of all Asian languages $)^{101}$ may point to an awareness on the part of Hell that the theory put forward in the Demonstratio is likely to evoke resentment and needs

98 György Szabados, A magyar történelem kezdeteirőll: Az előidö-szemlélet hangsúlyváltásai a $X V$-XVIII. században (Budapest: Balassi Kiadó, 2006) 14, 19. Hell also planned to include Anonymus's Gesta in the Expeditio litteraria. Sajnovics, Demonstratio (1771), 130.

99 See several studies in Martyn Rady, ed., Custom and Law in Central Europe (Cambridge: Centre for European Legal Studies, 2003).

100 For a brief introduction to this tradition and its ideological significance, see László Kontler and Balázs Trencsényi, "Hungary," in European Political Thought 1450-1700: Religion, Law, and Philosophy, ed. Howell Lloyd, Glenn Burgess, and Simon Hodson (New Haven: Yale University Press, 2007), 176-207, here 180-81, 185-86; for more details, see Jenő Szűcs, "Theoretische Elemente in Meister Simon de Kézas Gesta Hungarorum (1282-1285): Beiträge zur Herausgestaltung der 'europäischen Synchronismus' der Ideenstrukturen," in Szűcs, Nation und Geschichte (Cologne: Böhlau, 1981), 263-328.

101 For the ascription of this proposition to Hell, and its divergent linguistic grounds- the emphasis on monosyllabic roots in Chinese as well as Sámi and Hungarian; the application of metathesis and reading words backward, etc.- -from the overall thrust of Sajnovics's approach, see Vladár, "Hell mint nyelvész," 338-40. 
attenuation. ${ }^{102}$ Although in private correspondence Hell repeatedly expressed to Pray his reservations about de Guignes's original thesis, ${ }^{103}$ to his mind the only consequence of his and Sajnovics's findings for Pray's analysis was the need to add Sámi to the Hun-Hungarian combination. He expressed his hope that Pray would do this in his forthcoming work, and offered to "share my arguments and the authors on the question with Your Reverend, so that you may turn them to your own use."104 The same kind of "attenuation" was obviously the purpose of the additions extolling the beauty and the richness of the Sámi language, as a repository for the improvement of Hungarian, ${ }^{105}$ and even more of the references to the courage and valiance of the Lapps. ${ }^{106}$

There was indeed a great deal of anti-Sámi prejudice in contemporary literature to dispel if Sámi-Hungarian kinship was to be made appealing. The representation of Sámi in the standard international works-like the abovementioned Lapponia (1673) by Schefferus or the Géographie historique, ecclésiastique et civile (Historical, ecclesiastical and civil geography [1755]) by Maurist scholar Dom Jean-Joseph Vaissète $\left(1685^{-1756)}\right.$-was patently unflattering. In these accounts, the Sámi are described physically as of a small stature, and thin; their skin inclines to black because of the perpetual smoke in their tents; they have a large head and a protruding thorax, and small, cavernous, rheumy eyes; their nose is short and flat, their chin elongated, their mouth large and always open. They walk humped. With respect to customs and manners, "for most of the year they have little society among themselves, as they live in the forest among the wild beasts; and each family is separated from the others by a vast stretch of land." They are "cowardly and timid, and abhor war, which they never wage"; they are "cunning, and they sometimes cheat in trade."107

These stereotypes were faithfully reproduced in works of the same genre published in Hungary in the decades around the publication of the

\footnotetext{
102 Readers of the 1771 edition of the Demonstratio also familiar with Pray's Annales could easily make the inference that Sámi were herewith to be included in the Hun-Hungarian community (originally forged in China).

103 Hell to Pray, April 14, 1770. ELte EK, G 119. no. 169; Hell to Pray, January 4, 1771. ELte EK, G 119. no. 168.

104 Hell to Pray, April 14, 1770. ELTe EK, G 119. no. 169.

105 Sajnovics, Demonstratio (1771), 82-83, 107-10.

106 Sajnovics, Demonstratio (1771), 119-29.

107 Dom [Jean-]Joseph Vaissète, Geographie historique, ecclesiastique et civile, ou description de toutes les parties du globe Terrestre, enrichie de cartes géographiques (Paris: Desaint \& Saillant, Jean-Thomas Herissant, Jacques Barois, 1755), 101, following Scheffer. It was little compensation that their bodies are still acknowledged to be "well proportioned, without being deformed," and they are said to be "charitable and hospitable, and not without talent, because they produce all their utensils with much adroitness."
} 
Demonstratio. ${ }^{108}$ The Sámi are characterized in these in a vocabulary used in contemporary stadial history 109 to describe "savage" societies as yet resisting the influences of their more civilized neighbors. They invariably emphasize the bodily feebleness of the Sámi, ${ }^{110}$ and the consequent lack of military prowess among them, ${ }^{111}$ though one source claims that "once upon a time, six hundred Lapps put twenty thousand Muscovites to flight."112 Occasionally, the characterization of their physical features is conceived as a part of the general presentation of polar peoples. Thus, Sámi are linked with Fuegians, described as "the most inferior variety of our human kind" whom "it is impossible to behold without compassion and repugnance"; "according to some writers, they

108 We are grateful to Ildikó Sz. Kristóf for having shared with us findings of her unpublished primary research, thanks to which we first became aware of the works mentioned in notes 110-19.

109 The literature on Enlightenment stadial history, classifying human societies according to progress in their mode of subsistence from hunting-gathering through pasturing to agriculture and commerce, and more generally the "sciences of man," would fill a small library. Selectively, see Gladys Bryson, Man and Society: The Scottish Inquiry of the Eighteenth Century (Princeton: Princeton University Press, 1945); Michèle Duchet, Anthropologie et histoire au siècle des lumières (Paris: Albin Michel, 1971); Antonello Gerbi, The Dispute of the New World: The History of a Polemic 1750-190o (Pittsburgh: University of Pittsburgh Press, 1973); Ronald L. Meek, Social Science and the Ignoble Savage (Cambridge: Cambridge University Press, 1976); Peter J. Marshall and Glyndwr Williams, The Great Map of Mankind: Perceptions of New Worlds in the Age of Enlightenment (Cambridge, MA: Harvard University Press, 1982); Anthony Pagden, The Fall of Natural Man: The American Indian and the Origins of Comparative Ethnology (Cambridge: Cambridge University Press, 1986); Pagden, European Encounters with the New World (New Haven: Yale University Press, 1993); Roxann Wheeler, The Complexion of Race: Categories of Difference in Eighteenth-Century British Culture (Philadelphia: University of Pennsylvania Press, 200o); Hans Erich Bödeker, Philippe Büttgen, and Michel Espagne, eds., Die Wissenschaft vom Menschen in Göttingen um 1800 (Göttingen: Vandenhoeck \& Ruprecht, 2008); Silvia Sebastiani, I limiti del progresso: Razza e genere nell'Illuminismo scozzese (Bologna: Il Mulino, 2008), and the revised English edition, The Scottish Enlightenment: Race, Gender, and the Limits of Progress (Houndmills: Palgrave Macmillan, 2013). For Hungarian resonances, see Olga Penke, Filozofikus világtörténetek és történetfilozófiák: A francia és a magyar felvilágosodás (Budapest: Balassi Kiadó, 200o); Péter Balázs, Biblia, história és bölcselet a felvilágosodás korában (Budapest: L'Harmattan, 2013).

110 [Johann Hübner], Geographica globi terraquei synopsis: A multis praesertim quod Hungariam attinet, erroribus, qui in Celeberrimo alias Geographo Hübnero, aliisque circumferuntur, expurgata; In qua omnium mundi Regionum, \& locorum situs pro Mapparum Geographicarum usu exactissime describuntur (Trnava: Acad. Societ. Jesu, 1755), 16o; [Pál Bertalanffi], Világnak Két-rendbéli ismerete: Elöször A' mint Istentôl teremtetett; Másodszor A' mint az Istennek, és a' természetnek Vezérléséböl az emberektöl külömbb-külömbbféle részekre, Országokra, Tartományokra, és kösségekre osztatott [...] (Trnava: Academia, 1757), 648; [László Baranyi], Rövid magyar geographia (Pest: Trattner, 1796), 129.

111 [Hübner], Geographica globi, 214.

112 Bertalanffi, Világnak Két-rendbéli ismerete, 648. 
form the link between humanity and the Troglodytes [i.e., apes]," though the author hastens to add in a Buffonian fashion that "all the different nations most probably descend from the same stock, as all nations mingle with one another, they procreate, and some of their offspring resembles the one, and others, the other nation."113 The continued adherence of the Sámi to "pagan darkness"114 and their primitive mode of subsistence and "beastly existence"115 is another persistent feature of their representation in these works. Some authors elaborate on this by emphasizing the complete lack of agriculture and any other domestic animals than reindeer (which they utilize to full extent, including the drinking of their blood), ${ }_{1}^{116}$ their simple domiciles, and the dominant role of fishing and hunting. ${ }^{117}$ There are some important qualifications, too. One author asserts that while the Sámi are very ignorant and live among primitive conditions, "they are not as miserable as some people think," because they are "nevertheless satisfied with their lot, and live peacefully with one another."118 Elsewhere we learn that "they are regarded as ignorant, but an English traveler says: human love and affection is taught to polished nations; but in Lapponia, it is also exercised"119_ resembling, though on somewhat different grounds, Linnaeus's judgment of the Sámi as noble savages who may have something to teach civilized nations. ${ }^{120}$

113 [György Fejér], Anthropologia vagy is az embe'r esmértetése (Buda: Királyi Magyar Universitás, 1807), 152-53. For a similar analysis, see [Mihály Katona], Közönséges természeti Föld-leirás (Pest: Trattner, 1824), 452.

114 István Vetsei P[ataki], Magyar Geografiája: $A z A z$; Ez egész világ négy részeinek, ugymint Europának, Asiának, Afrikának és Amerikának;'s bennek levő sokféle országoknemzetségek; azok eredetek, természetek, 's nevezetesebb szokásainak, vallásainak, imperátorinak, királyinak, s több egyéb elmét vidámito hasznos dolgainak méltó és rövid le-irása [...] (Carei: Károlyi Ferentz Typographiája, 1757), 225.

115 Bertalanffi, Világnak Két-rendbéli ismerete, 649.

116 [Georg Christian Raff], Természethistoria a' gyermekeknek (Veszprém: Számmer Mihály, 1799), 537-38. On the reception of Raff's work in Hungary, see Ildikó Sz. Kristóf, “The Uses of Natural History: Georg C. Raff's Naturgeschichte für Kinder (1778) in Its Multiple Translations and Multiple Receptions," in Le livre demeure: Studies in Book History in Honour of Alison Saunders, ed. Alison Adams, Philip Ford, and Stephen Rawles (Geneva: Droz, 2011), 309-33.

117 György Raff, Geografiája a' gyengébbek elméjekhez alkalmaztatott, és magyarúl kiadattatott (Vác: Ambro Ferenc, 1791), 144.

118 Raff, Geografiája a' gyengébbek elméjekhez alkalmaztatott, 144. It is noteworthy that Raff's work usually refrains from presenting lifestyles (the other two exceptions being the Muscovites and the Poles).

119 [János Ferenczy], Közönséges geographia, mellyben a’ Földnek mathematikai, természeti, és leg inkább politikai állapotja a' leg ujabb változások után elő adatik (Pest: Eggenberger József, 1809), 153 .

120 Koerner, Linnaeus, 56-81. 
As a matter of fact, the same works also include — sometimes very lengthyaccounts of the peoples of the steppe, or Scythia, "an immensely large country occupying one-third of Asia," from where the Magyars had also once departed in search of a better land and where "even today, entire nations move around by the thousands because of the barrenness of the soil."121 They live mostly as nomadic shepherds - thus in a stage more advanced than the Sámi-and are also acknowledged to be bloodthirsty warriors. However, though the Greeks and Romans may have regarded them as barbarians,

it is very true of the Scythians that they achieved more good by relying on nature than the Greeks by all the learned instruction of their philosophers $[. .$.$] . In addition, this people never bowed to a foreign nation, they$ even founded the Parthian and Bactrian empire, they defeated Cyrus and Darius, they put Alexander the Great to nothing, and the Romans never dared to attack them.

Contradicting some earlier claims, it is stated that

though they are pagans, like some other nations in this world, they never had any idol either cast or carved, they respected marital life, they cultivated the art of war, and many of them did not eschew the sciences either; they even had philosophers, studied the rules of justice, and many other laudable things were found among them, for which reason the Apostle Paul distinguishes them from the barbarians, Col. 3:11. ${ }^{122}$

In these descriptions, in which the standard international knowledge on the subject was recycled for Hungarian audiences, we thus meet savages and barbarians, both of whom have some potential to be recognized as "noble." With regard to the reception and uses of this knowledge, because of the ideological aspects mentioned earlier, there was a strong presumption in favor of accentuating this potential in the case of "Scythians," and against the same in the case of the Sámi-even without the provocation of the Demonstratio. To pre-empt and counter this, Hell resorted, among other things, to a bizarre etymology of Carjelia (or Karjelia), supposedly derived from karjel: the Hungarian compound jel(es) kar (i.e., "illustrious arm"); and to lend further support to the representation of the "Lapps" of "Karjelia" as heroic warriors, he included the

121 Vetsei, Magyar Geografiája, 355, 357.

122 Vetsei, Magyar Geografiája, 360 (wrong pagination: properly 356). 
insignia of the region, representing two arms holding a sword and a spear (or an arrow?), found in the Blaeu atlas. ${ }^{123}$

Each of these topics, besides several others related to the origin and ancient history of the Hungarians, are discussed in notes and letters by Hell preserved among the papers of Pray, deriving from the period of the preparation and the aftermath of the publication of the second edition of the Demonstratio. ${ }^{124}$ As regards karjel, Hell claims that this is the form in which all of their local interlocutors referred to themselves, and in a letter to Pray he also underpins this from the Swedish description of Lapland by Pehr Högström (1714-84), published in Stockholm in $1747 .{ }^{125}$ Elsewhere, he claims to have heard the "Karjelian dialect" spoken among the Szekels of Transylvania, who supposedly migrated there from Karjelia itself with "King Attila."126 Hell's above-mentioned note was conceived as a response to Pray, who was apparently skeptical about Hell's explications. Another effort by the astronomer at etymological analysis, deriving Dentumoger - the name of the homeland of the Hungarians before the conquest of the Carpathian Basin in Anonymus's Gesta-from Dán-vadmagyar, "Danish-fierce-Hungarian," was dismissed by Pray in notes on Hell's manuscript as "violent distortion" and "gross ignorance."127

While these ventures of Hell into linguistics were clumsy, the zeal with which he pursued them and investigated a wide range of issues and sources of early Hungarian history are proof of his determination to be recognized as an expert in the field. Besides the exchanges with Pray, the evidence for Hell's infatuation with the history of Hungarians during the later stages of the steppe migrations, the conquest and settlement in the Carpathian basin, and the early period of the Christian monarchy includes items of correspondence with the two other leading Jesuit historians of the time, István (Stephanus) Kaprinai (1714-85) and István (Stephanus) Katona (1732-1811), as well as notes, drafts, and fragments undoubtedly intended to feed the pages of Expeditio litteraria. Hell delved into and discussed puzzles found in primary sources like Anonymus's Gesta and the Byzantine emperor Constantine VII Porphyrogenitus's (909-59, r.913-59) De administrando imperio (Of the governance of the empire

123 Sajnovics, Demonstratio (1771), 119-24 (the insignia, 122). It is noteworthy that wherever the region's name appeared in the 1770 edition, it was Careila (Karelia), i.e., without the “ $\mathrm{j}$ " that supported Hell's etymology.

124 These documents are included in the Collectio Prayana, vol. 18, Miscellanea, at the ELTE EK, now digitized; https://edit.elte.hu/xmlui/gallerymanager?reckey=HeadCollPrayo18\# drop (accessed April 16, 2019).

125 Coll. Prayana 18:25; Hell to Pray, February 5, 1772. ELTE EK, G 119. no. 162.

126 Hell to Pray, March 29, 1771. ELte EK, G 119. no. 165.

127 Coll. Prayana 18:23. 
[c. 948-52]), written to his successor as a governance manual, and containing a great deal of material, including histories and legends, about neighboring peoples. ${ }^{128}$ He even took inspiration from these to prepare historical maps, and brooded over questions like the "original homes" of the Magyar tribes as well as the peoples they encountered and mingled with during their migration - the Khazars and Khazaria figuring especially prominently among them - the date of the birth of the founder of the state, King Saint Stephen I (c.970/75-1038, r.1000-38), or the later immigration of further nomadic groups like the Jazigs and Cumans into the medieval Kingdom of Hungary. ${ }^{129}$

Given this deep and systematic immersion, by the time of the Trnava edition of the Demonstratio Hell's swelling self-confidence in the field led him to strike an increasingly polemical, even resentful tone. Writing to Pray on February 5, 1772, he still regarded the historian as an ally, requesting his support in countering some disparaging comments on the Demonstratio in von Schlözer's Allgemeine nordische Geschichte. In his work, von Schlözer charged Sajnovics with ignorance of the migration of his own Hungarian people. Hell

128 Two chapters of the Expeditio litteraria were supposed to be devoted to Anonymus and to Constantine, respectively. For modern editions, see Anonymus and Master Roger, Anonymi Bele Regis Notarii Gesta Hungarorum/Anonymus, Notary of King Béla, the Deeds of the Hungarians, trans. and ed. Martyn Rady and László Veszprémy; Magistri Rogerii Epistola in Miserabile Carmen super Destructione Regni Hungarie per Tartaros Facta/Master Roger's Epistle to the Sorrowful Lament upon the Destruction of the Kingdom of Hungary by the Tatars, trans. and ed. János M. Bak and Martyn Rady (Budapest: Central European University Press, 2010); Constantine viI Porphyrogenitus, De administrando imperio, Greek text ed. Gyula Moravcsik, English trans. R.J.H. [Romilly James Heald] Jenkins, commentary by F. [Francis] Dvornik (Washington, DC: Dumbarton Oaks, 1962-67).

129 Besides the letters to Pray already mentioned, Constantine Porphyrogenitus and Anonymus are also discussed in Hell to Pray, January 10, 1771 and January 28, 1772, ELTE EK G 119. nos. 167, 161; Khazaria in Hell to Pray, January 18, 1772, ELTE EK G 119. no. 161. Anonymus is the central subject in Hell to Kaprinai, January 28 and February 18, 1772, and Kaprinai to Hell, February 16, 1772. ELTE EK, Coll. Kaprinayana, 66:nos. 2-4 (the original of the latter one, dated February 15, 1772, with a slightly different wording, is held at the wus MS Hell, 4:no. 47) As late as November 2, 1776, Katona sent Hell long reflections on Porphyrogenitus, wUs MS Hell, 4:no. 53. The relevant drafts and fragments by Hell (all of them undated) are also held at the wUs, MS Hell, vol. 4, and include: "Notitia regni Ungariae anno 886. ante adventum Ungarorum" (no. 26); "Criteria ad indagadandam, et definiandam statem Scriptae Historia Anonymi Regis Belae Notarii de vir Ducibus Ungariae. ex ipso Auctore deducta" (no. 36); "Synopsis Chronologico-Geographico-Historica Adventus Ungarorum in Pannoniam Seculo IX. Ex Anonymo Regis Belae Notario, et Constantino Porphyrogenetae De Administrando Imperio" (no. 40); “Disquisitio Critica de Cumanis" (no. 41); "De Primis Ungarorum sedibus seu Natali solo Ungarorum" (no. 58); "De Anno Nativitati S. Stephani" (no. 85); "Dissertatio de Ultimo Ungarii adventa in Pannoniam seu Hodiernam Ungariam” (no. 97). 


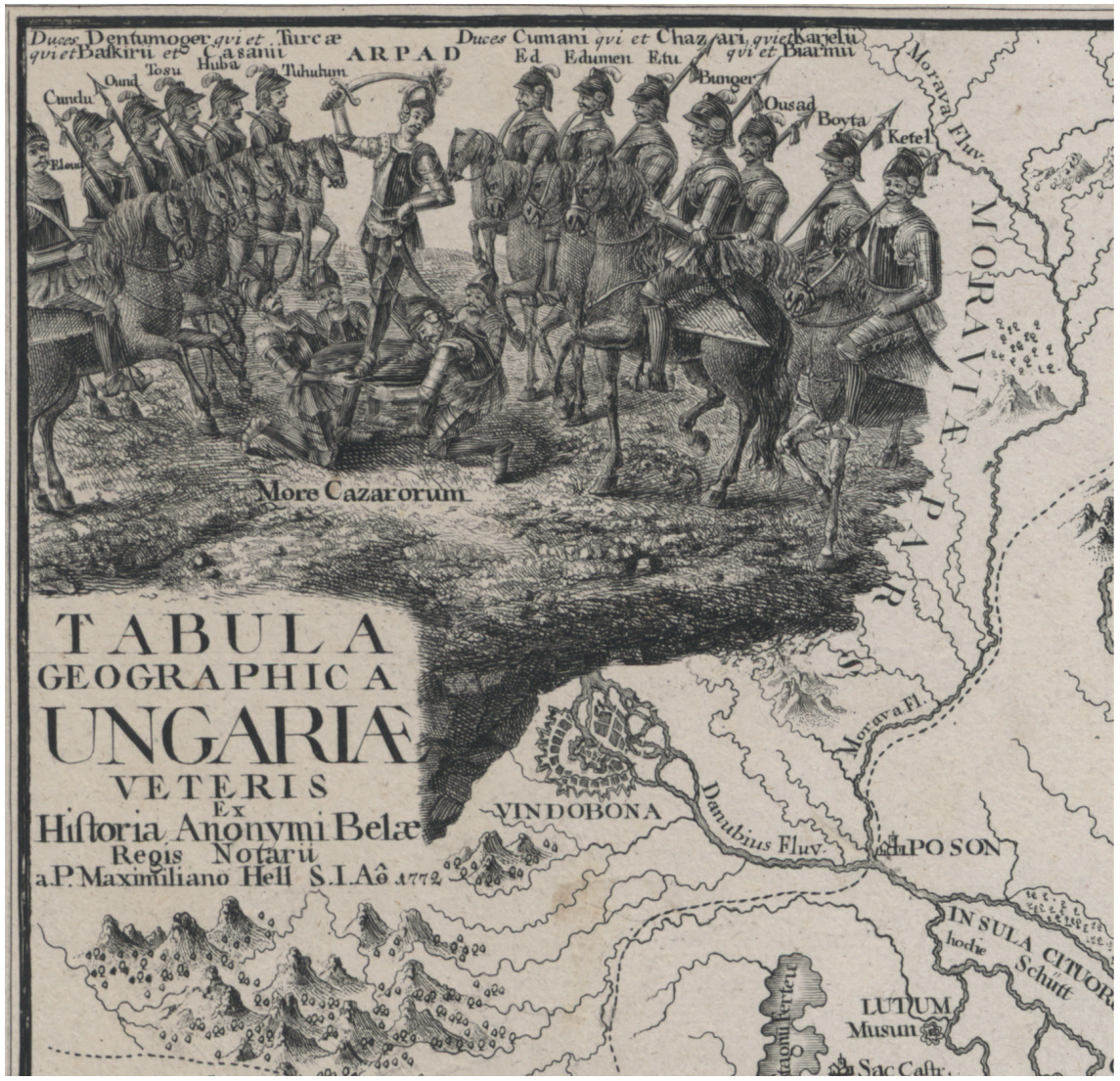

FIGURE 12 Prince Árpád acknowledged as principal leader by raising him on the shield ("in a Khazaraian style") by the Magyar chieftains and their allies

From a map of ancient Hungary drawn by Hell on the basis of Anonymus's Gesta Hungarorum (Tabula geographica Ungariae Veteris Ex Historia Anonymi Belce Regis Notarii, a P. Maximiliano Hell S.I. Gabriel Ruderstorffer [Vienna, 1772]). Hungarian National Library, Map Department, TR 378.

retorted that this was just because von Schlözer only had access to the Copenhagen edition (to amend which Hell arranged for a copy of the Trnava edition to be sent to Göttingen); besides, the German professor was misled in his own notion of the original home of the Hungarians by his fallacious spelling of "Magyar" as "Madschar," and by using the wrong sources and methodology (Fischer, geographer Johann Gustav Gärber [1690-1734], and renowned Swedish polymath Olof [Olaus] Rudbeck [1630-1702]). Soon after Hell sent this letter to Pray, he also received one from von Schlözer, thanking Hell for sending the Trnava edition of the Demonstratio, but reiterating some of the German 
scholar's objections. ${ }^{130}$ Hell asked Pray to include a critique of von Schlözer in his forthcoming Dissertationes historico-criticae in annales veteres Hunnorum, Avarum et Hungarorum (Historical-critical investigations of the old annals of the Huns, Avars, and Hungarians, eventually published in 1774 in Vienna and again in 1775 in Bratislava). ${ }^{131}$

The hope that in this work Pray would highlight the contribution of the Demonstratio had already been expressed in one of the additions to the text of the Trnava edition of Sajnovics's treatise: "Whether our eminent historian, Father Georgius Pray, adopted any of the claims put forward by these authors [i.e., various authors supporting the Finno-Ugrian theory], he will show himself to the erudite world in his finely conceived Dissertationes, to be published soon." ${ }^{132}$ Hell's response to Pray on the interpretation of karjel, already mentioned above, also records the disappointment of this expectation. While in the Dissertationes Pray revised his overall theory to include the Finns, besides the Huns, Avars, and Hungarians in the common narrative of origin from China, and acknowledged his debt on this point to Hell and Sajnovics, already at the beginning of the work he signaled disagreement with certain aspects of the Demonstratio, which in the elaboration turned out to be particularly the coatof-arms and the etymology of Karjelia. ${ }^{133}$ Hell, probably familiar with the manuscript of the Dissertationes, was fuming in his note to Pray. His strategy of dismissing the latter's counterarguments-based on the lack of empirical evidence for the word-formations asserted by Hell on syllogistic grounds-is strongly anchored in stressing the superiority of his method of deduction based on "stringent formal logics and proof" characteristic of his own discipline. ${ }^{134}$ Hell almost addresses a threat to Pray on this account: "Therefore I must request the respected author to keep quiet [...] unless he wishes to make an enemy out of me, the mathematician and thus the severest of critics."135

130 Von Schlözer to Hell, February 29, 1772, published by Ferdinánd Mencsik, Magyar Történelmi Tár, 4th series, 6 (1905): 143-47.

131 Hell to Pray, February 5, 1772, ELTE EK, G 119. no. 162.

132 Sajnovics, Demonstratio (1771), 129. Cf. the tentative formulation in the 1770 edition, 82: "Whether Father Georgius Pray, the eminent author of the Annales Ungariae, has adopted any of their claims, I am as yet unable to tell."

133 György Pray, Dissertationes historico-criticae in annales veteres Hunnorum, Avarum et Hungarorum (Vienna: Bernard, 1774), 1, 18, 28, 43, 66-68. Cf. the discussion in Vladár, "Hell mint nyelvész," 343-47.

134 In the letter mentioned above in n. 130, von Schlözer was also highly critical of the inflexibility of Hell's method, e.g., his insistence that the "identity" means the sameness of all roots except borrowals and extinct words.

135 Coll. Prayana 18:25. 
This aspect of Hell's response also points to the difficulty of conceiving an all too obvious and sharp wedge between the deductive and inductive method in the sciences: as a competent practitioner in astronomical observations, his credentials as a sound empiricist were good enough, but he had no qualms representing himself as the impeccable deductionist when this suited his polemical purposes. In his defense against Pray, the haughty confidence of the representative of the exact sciences over the mere student of the humanities also spills into ad hominem argument: Pray's objections are dismissed as "lacking any rationality," "ridiculous," even "stupid."

But Hell was upset not only because of the challenge to "his system" but also because he felt it was not properly recognized as "his." This is the aspect in which the debate on substantive issues tackled in the Demonstratio becomes intertwined with the problem of attribution. At the very outset of the response, Hell writes: "I do not know what came to the mind of the illustrious author to persecute my things (for all that Father Sajnovics writes in his treatise about the origin of the Hungarians is mine [italics added]) with such venom [...]."136 In another undated note to Pray, this time called "Animadversiones" (Remarks), Hell gives full vent to his consternation upon the perceived neglect of his role. ${ }^{137}$ He opens the document with a complaint at Pray's allegation, in a 1768 epistle refuting the Piarist Benedetto (Benedictus) Cetto's (1731-99) account of the "Chinese rites controversy,"138 that Sajnovics was invited to participate in the Vardø expedition along with Hell by the Danish king. As Hell stresses, the invitation was delivered "most privately to me alone [...] by the Danish ambassador," and after the necessary negotiations with Kaunitz and the government had been conducted, he himself chose Sajnovics as his assistant and travel companion. To make things fully unequivocal, he added:

136 Coll. Prayana 18:25.

137 Coll. Prayana 18:24.

138 This was a debate among different groups of Catholic missionaries concerning the interpretation and status of rites in Confucianism and Chinese imperial practices. The Jesuits claimed that these were essentially secular and thus, within certain limits, to be tolerated, while Dominicans and Franciscans argued that they were incompatible with Catholicism and therefore were to be combated. The Vatican adopted the latter position and banned the rites for Chinese Catholics. For a comprehensive discussion, see George Minimaki, The Chinese Rites Controversy: From the Beginnings to Modern Times (Chicago: Loyola University Press, 1985). Pray's commentary on Cetto was eventually published as the Imposturae cCXVII in dissertatione R.P. Benedicti Cetto Clerici Regularis e Scholii Piis, de Sinensium impostoris detectae, \& convulsae (Buda, 1781) and then incorporated in the Epistola ad Benedictum Cetto e piis scholis in qua novae huius in rebus sinicis imposturae deteguntur: Accedit historia controversiarum de ritibus sinicis [...] (Buda: Strohmayer, 1789). In these publications, however, there is no reference to Hell, Sajnovics, and the Demonstratio. 
Nothing, therefore, of all this has to do with Father Sajnovics, nor does any of the other research made during the expedition pertain to him; except that [he] assisted me in some tasks according to my instructions and my ideas; thus, whatever has been revealed, elaborated, discovered, and so on, has to do with me only, and the demonstration of the identity of the Lappish and Hungarian language, as regards the structure of the work, the arguments, its elaboration, and so on has itself been accomplished according to my ideas and instructions, so that if I had not personally assisted, Hungary today would not be aware of this linguistic identity; out of his own initiative, Sajnovics certainly would not have accomplished this work, he always opposed my opinion, I had to take this labor in my hand, and he saw how gravely I was affected by his repugnance toward me and the job. ${ }^{139}$

Hell explained that the exact particulars of the division of labor between him and Sajnovics were left obscure in the first edition of the Demonstratio because while in Copenhagen he wanted benevolently to promote Sajnovics, to be treated there "not as an assistant or a disciple, but as a good companion of mine, and therefore I arranged his election, after my own, to the academies of Trondheim and Copenhagen, and even he has to acknowledge that he owes this solely to me." But this was to be over: Hell revealed to Pray that in the forthcoming Expeditio litteraria he had no intention of identifying Sajnovics as an author of the relevant part (to be based on the Demonstratio), and in the meantime demanded that "everything concerning my Expeditio that is in the plural on the first and second page [of Pray's epistle], ought to be separated, and either to be tied exclusively to my person, or deleted."140

139 Coll. Prayana 18:24. This document was first highlighted by András Vértes at the conference of the Hungarian Society for Linguistics on October 26, 1971, and analyzed in Anna Jászó, “Deux études sur János Sajnovics," Études Finno-Ougriennes 16 (1983): 255-61. Cf. Vladár, "Valójában ki a szerzője," 322.

140 Coll. Prayana 18:24. This reminds one of the changes inserted in the advertisement of the Expeditio litteraria. In an early manuscript draft to the call for subscriptions, Hell points to Sajnovics as the author of a chapter of the first volume: "The treatise of Father Sajnovics on the identity of the Hungarian and Lappish language." In all printed versions, however, the name of Sajnovics was erased, and Hell promises only a chapter on "the origin and occasion of this investigation of the Lappish language." Pray complied with Hell's requests to the extent that in the first pages of the Dissertationes Hell is mentioned as the sole recipient of the invitation, who then took along Sajnovics. As far as the authorship of the Sámi-Hungarian theory is concerned, Pray consistently ascribed it to Sajnovicsquite naturally, as no edition of the Demonstratio was ever published under any other name than his, and Hell's publication plans on the subject came to nothing. 
It is quite noteworthy that just as Hell's debate with European astronomers concerning the solar parallax (to be described in the next chapter) was unfolding, he threw himself, with increasing determination, into another controversy on the other substantial finding of the expedition on the home front. The explanation is probably that he realized with ever greater clarity the importance of the subject matter generally on the map of learning and specifically for the educated public of his fatherland, and wanted to capitalize on exaggerating his own role in attaining the results. Judging from the fervor with which he engaged in the debate, the stake of which was ultimately the unsettling issue of identity, Hell the man of the "exact sciences" was ready for a conversion into a cultural theorist-importantly, as we have seen, also attempting an act of methodological colonization. In regard of this conversion, it is worth observing that while in the first edition of the Demonstratio only Sajnovics is referred to as a "Hungarus," in the second one, issued about ten to twelve months later, ${ }^{141}$ Hell is also mentioned as such on several occasions. These were the beginnings of a process, to be amplified during the 1770s, of Hell's (re)discovery of his

141 It is often overlooked that the year of printing is missing on the title page of both the first and the second editions of the Demonstratio. The Copenhagen edition states: Regiae Scientiarum Societati Danicae praelecta Hafniae mense Januario anno MDCCLXX (Read before the Royal Danish Society of Sciences in Copenhagen, in the month of January of the year 1770). The Trnava edition reads: Regiae Scientiarum Societati Danicae praelecta, et Typis excusa Hafniae anno MDCCLXX: Recusa Tyrnaviae (Read before the Royal Danish Society of Sciences, and printed in Copenhagen in the year 1770: Reprinted in Trnava). The date of publication is well documented in the case of the first edition: on March 4, the proofs were still being read, but on April 10, 1770, Sajnovics received a copy fresh from the press (Sajnovics, travel diary, entries for March 4 and April 10, 1770 [wUs]). The second edition is not that easy. Correspondence confirms, however, that it was published later than January 1771, for in a letter to Pray in Bratislava Hell writes: "Father Sajnovics will hardly be able to go to Vienna in the month of January, and I doubt that his work will be ready from the press in this month either: if he can manage to come around the end of February, I shall be happy" (Hell to Pray, dated Vienna, January 4, 1771 [E LTE EK G 119. no. 168]). In a letter dated January 10, 1771, Hell asks Pray to pass on some papers to Trnava "for the new edition of Father Sajnovics's work." It is crucial that Pray takes care of this task as soon as possible, he adds, "for without this, Father Sajnovics has so far been unable to begin his work" (Hell to Pray, dated Vienna, January 10, 1771 [E LTE EK G 119. no. 167]). From a letter dated March 29, 1771, it emerges that Sajnovics had by then arrived in Vienna, probably to promote the new edition of the Demonstratio (Hell to Pray, dated March 29, 1771 [ELTE EK G 119. no. 165]). By May of the same year, Sajnovics had returned to Trnava and could boast about the favorable reception that his work had received in Vienna (Sajnovics to Joannes Nagy, dated Trnava, May 12, 1771. See transcript in Flórián Holovics, "Sajnovics János a Demonstratióról," Magyar Nyelv 68 [1972]: 432-501). For a good discussion of the internal evidence in the printed text of the Tyrnavian edition, see also Danilo Gheno, "Sajnovics e la Demonstratio: Problemi e caratteri dell'edizione di Trnava," Atti e memorie, Accademia patavina di scienze, lettere ed arti 87 (1975): 45-59. 
identity as a Hungarus patriot and public fashioning of himself in that role. Further manifestations of these efforts, as well as responses to them, will be discussed in Chapter 8. Here it should suffice to draw the balance as to the probable real division of labor between Hell and Sajnovics on the SámiHungarian kinship and origins with reference to an earlier statement by Hell himself, which may also throw further light on the genealogy of this aspect of the expedition. This is how Hell wrote on the subject, while still in Vardø, to Pilgram, his substitute at the Imperial and Royal Observatory in Vienna:

[You] must have had a prophetic spirit, when You in Your letter to Sajnovics wrote: 'I salute the dark pastorella a thousand times,' and 'I expect Lappish eclogues from him'; in fact, You, and the entire European world of learning may expect concerning the Lappish race a new discovery, which will be received with bewilderment by entire Europe. I, who formed this conjecture about the Lapps from the very beginning, gave him some rules and criteria, according to which he was to do this research, and now we have reached such clarity, that no human being will doubt this. Indeed, indeed, Sajnovics is in fact able to make "Lappish eclogues"; I am quite satisfied to have chosen him as my travel companion, he who so readily and in such a brief span of time was able to learn the Lappish language. I have asked him to extract some memorable stories from our diary and send them to [You], so that You may share them with our friends in Vienna. [...] I beg you, however, to please make sure this discovery arrives to the ears of Mr. van Swieten; he will find pleasure therein, since he was the one who bade me do this investigation [italics added]; but please give him only the general information that they [the Sámi] are no Americans, but real Orientals, as we will have the honor to inform him in detail upon our return. ${ }^{142}$

Writing privately to a colleague vis-à-vis whom there was certainly no need to promote Sajnovics in the ways Hell alleged doing it toward their Copenhagen audience, Sajnovics is effectively acknowledged to have mastered - to Hell's own great satisfaction - the skills necessary for the research, and also to have pursued it, albeit building on a "conjecture" and following "rules and criteria" that Hell claims originated from himself. Or maybe not: interestingly, he effectively contradicts himself just a few sentences below, where the initiative is ultimately attributed to the man who stood behind virtually all the innovative

142 Hell to Pilgram, Vardø, April 5, 1769 (wus), printed in Pinzger, Hell Miksa, 2:67-68. 
transformations of the academic scene in Vienna during the previous two decades: Gerhard van Swieten. ${ }^{143}$

Van Swieten may well have been the implacable opponent of the Society of Jesus that he is usually described as being, but as we have seen, in his campaign against "vampirism" he resorted to an argumentative strategy familiar from Jesuit polemics against superstition, and competent and qualified Jesuit savants still retained important positions under his regime. On this occasion as well, he apparently found it possible to cooperate with them. However, one may also conjecture that one further step was included, and that Van Swieten, who is not known to have ever studied linguistics and the problems of language kinship, relied on expert advice in instructing Hell to do so. There is at best circumstantial evidence for identifying Van Swieten's potential source. Hell's apparently strange prompt that the Sámi "are no Americans, but real Orientals" may provide a clue. Notions about the peopling of America from Asia, and thus an ethnic and linguistic link between the indigenous peoples of both continents, were already in circulation at the time. ${ }^{144}$ The man in Vienna known for both his prodigious command of Oriental languages and his inquiries into native American cultures (including the curating of a carefully assembled collection of artefacts) was the first custodian of the Imperial and Royal Library, hired there by Van Swieten and the direct subordinate of the latter as the director of the institution: Adam František (Franz) Kollár, already introduced in Chapter 1 as a fellow novice of Hell in Trenčín in the 1740s. Kollár must also have been eagerly awaiting the publication of the linguistic results of the Vardø expedition. He was aware of the Copenhagen edition of the Demonstratio as well as at least the main elements of the theory it contained as early as May 1770. ${ }^{145}$ Shortly after, he thanked Pray for sending excerpts of the early

143 Naturally, the explicit ascription of the inspiration behind the investigation of linguistic kinship to Van Swieten relativizes the doubt expressed earlier about the purposiveness of the enterprise. The puzzle may be resolved by surmising that clues about the topic were supplied to Hell and Sajnovics from Vienna not prior to their departure but in correspondence while already en route, but no surviving letters known to us support this.

144 Several passages in Buffon's Histoire naturelle, based on accounts of Jesuit missionary and traveler Pierre-François-Xavier de Charlevoix (1682-1761), played a prominent role in giving the idea currency. See, e.g., Georges-Louis Leclerc Buffon, Histoire naturelle, générale et particulière (Paris: Imprimerie Royale, 1749), 1:224-25.

145 In a letter of May 29, 1770, his friend, teacher and jurist József Benczur (1728-84), thanked Kollár for reporting (in two letters that are not extant) about Sajnovics's discovery of peoples in the Arctic "who ought to be reckoned as the brothers of Hungarians," expressed his hope that the book would be reprinted once the author was back in Vienna, and asked Kollár to help him obtain a copy of the book. However, Benczur, who "easily allowed that our Hungarians are not the descendants of Attila's Huns," also warned that "our 
thirteenth-century "Funeral Oration," the earliest surviving document written in the Hungarian language, and-believing "Lappish" to be an archaic "dialect" or variety of Hungarian - expressed his hope that "your Columbus, your Vespucci" (i.e., Sajnovics, who had apparently mastered Sámi) would be able to read, pronounce, and understand it impeccably. ${ }^{146}$ In December 1770 - only eight months after the book appeared, and four months after Hell and Sajnovics arrived back in Vienna—Kollár published a review of it in the second issue of a brand new Viennese journal dedicated to "sciences, arts, and commerce."147

The review is essentially positive. The only criticism concerns the origin of a few words, Hungarian according to Sajnovics but Slavic according to the reviewer (who was correct on this point). ${ }^{148}$ Apart from this, Kollár commended the whole enterprise-mentioning the invitation to Hell, characterized remarkably as another "born Hungarian" (gebohrnen Ungar) - as well as the sound methodology and the convincing findings. Especially noteworthy are a few sarcastic remarks, aimed at theories "destroyed" according to Kollár by Sajnovics's successful "demonstration," and pre-empting the likely opposition against it. "Our learned author should not be looked for among the ranks of those who, even a short time ago, presumed to find the Hungarian nation and language through a laughable effort in the Sinai peninsula,"149 Kollár writes, referring to the old tradition of deriving Hungarian from Hebrew (also explicitly rejected in the Demonstratio). Before concluding the review by "publicly thanking the learned father Sajnovics for the excellent present brought along from the distant north," Kollár describes the "undoubtedly very great" benefits of the book as follows:

Only from now on can the Hungarians, the Lapps, the Finns, and others become more exactly familiar with themselves and their Scythian origin: only from now on can learned men acknowledge the difference between the Scythian and the Turkish language.

Hungarians may have the intention to prevent in every way" the republication of the Demonstratio, because they "do not want to believe that they have relatives in Lapland." The letter was published; see István Salánki, “Levél Sajnovicsról," Magyar Nyelv 60 (1964): $250-52$.

146 Kollár to Pray on June 12, 1770, in Soós, Kollár levelezése, 207.

147 [Adam František Kollár], "Joannis Sajnovics S.J. Ungari Tordasiensis \& c. Demonstratio idioma Ungarorum et Laponum idem esse," Realzeitung (December 1770): 18-23. Kollár is identified as the anonymous author of the review, and the whole of the text is included with commentaries in Zoltán Éder, "Sajnovics Demonstratiójának első recenziója: 'Viennensis Recensitor opusculi mei Hafniae editi," Magyar Nyelv 110 (2014): 85-94.

148 The critique is rejected in the Trnava edition of the Demonstratio (1771), 72-73.

149 [Kollár], "Joannis Sajnovics S.J. Ungari Tordasiensis \& c. Demonstratio," 19. 
Therefore it would be desirable that after this fortunate discovery about the Scythian peoples and languages no one dares to write of the Huns, whom many have considered the forefathers of the Hungarians; at first, they should learn more about the Scythian and the Turkish language, following the example of our Sajnovics, who leaving behind his homeland took long journeys in northern Europe and in Asia [sic]; despite this, some do not cease building imaginary systems before assembling sufficient material from experience $[. ..]{ }^{150}$

The tenor of these remarks appears to belong to someone imbued with a sense of triumph over having received what he had expected and hoped for. As we shall see in more detail, by this time Kollár had been engaged for several years in polemical activities directed at the political and fiscal privileges of the Hungarian nobility. He thus had a distinct stake in emphasizing that the Demonstratio dealt a blow to the Hun-Hungarian discourse of origin and identity, which was one of the cornerstones of the noble ideology—although as a scholar he also pretended to suspend judgment, and addressed to the opponents a rhetorical invitation to counter Sajnovics on the ground of as abundant and sound empirical evidence as he had collected in support of his own argument. Whether or not Kollár played a role, via Van Swieten, in instigating the linguistic inquiry of the expeditionists, the results satisfied him greatly, and his contributions had an important part in the development of an atmosphere in which the credibility of Hell's efforts to present himself as a Hungarus patriot in the 1770s was questionable in the eyes of a broad segment of the country's elite.

\section{4}

\section{Authority Crumbling}

The items discussed in this chapter all point to a Maximilian Hell prepared to vindicate his place as the hero who "came, saw, and conquered" all obstacles, emerging as the celebrated and unquestionable authority on everything from natural history and geophysics to linguistics and astronomy. Nothing went according to plan. On some of these subjects, he either failed to publish anything at all (as in the case of morild and other zoological and botanical matters) or published much too late (posthumous weather reports with climatic deliberations); on others, he encountered problems of attribution (the linguistic

150 [Kollár], "Joannis Sajnovics S.J. Ungari Tordasiensis \& c. Demonstratio," 22. 
studies of Sajnovics) and even fierce opposition (the historical theories building upon them), or, worse still: disinterested silence from the theoreticians that he most of all would have wanted to reach (the theory on the aurora borealis). In short, instead of relishing the comforts of fame both home and abroad, Hell saw his authority under attack from virtually all sides. His fierce and often puerile reactions indicate a man with his back against the wall, jealously protecting what is left of his standing in the Republic of Letters. Nowhere was his public response more verbose than when he felt his credibility as an astronomer questioned. The next chapter deals with what would have become the third and fundamental part of the Expeditio litteraria: the "mathematical and astronomical volume," or Tomus mathematicus \& astronomicus. 